\title{
Federal Government Initiatives to Reduce the Price Level
}

THEORIES of the origins of inflation and the effects of price increases on a mixed market economy abound; as a result, there is no widespread consensus as to how to restrain inflation efficiently while maintaining high employment levels and a healthy rate of economic growth. There is little dispute, however, that the government's varied microeconomic policies have substantial price effects. At a time when inflation is a major concern and there is no accepted general policy for its containment, the federal government should explore ways to lower the price level through a variety of basically microeconomic policy decisions.

This paper focuses on options that are currently available to the federal government for lowering the price level. While these options are disparate and not easily synthesized into a simple framework, most have a similar theme: pursuing objectives through direct rather than indirect taxation, where "indirect taxation" includes government-mandated cost increases for producers of private goods and services. For a number of reasons, government programs are often financed through increases in producer costs rather than through direct payments from general government revenues. In some instances, such as when user taxes are levied, there is an equity or efficiency reason for doing so. In others, such as health and safety regulation, the reason is largely pragmatic: mandating cost increases for producers is simply the easiest (not the most efficient) means of achieving the desired objective. But in still other cases, such as agricultural policies or minimum wage legislation, programs are financed

Note: I wish to thank Jeffrey A. Goldstein for his research assistance. 
through increases in the price level because direct payments to the targeted population might not pass the scrutiny of the electorate.

In this paper I do not analyze the efficiency gains that could be derived from various proposals. These gains are likely to be large and are often related to price-level effects, if only imprecisely. For instance, a less "inflationary" farm policy is also likely to increase allocative efficiency. The same is true for deregulation of the airline industry. In a few cases, such as the deregulation of natural gas, crude oil, and petroleum products, however, the efficient policy would lead to higher deregulated prices, and the inflationary cost of such a policy shift would then have to be weighed against its benefits. But these are the exceptions. Most of the initiatives discussed here can be embraced both by those interested in eliminating economic waste and by those concerned with containing the upward movement of the price level.

\section{Calculating the Effects of Policy Initiatives on the Price Level}

In addition to monetary and fiscal policies, the federal government has a major influence on the price level through the payroll taxation for old age and survivors, disability, and health insurance; indirect taxation, agricultural price supports; economic regulation of such industries as communications and transportation; social regulation of the environment, health, and safety; trade protection; minimum wage legislation; and subsidization of health insurance. In a single paper, it is impossible to estimate the full effects on the price level of all policies pursued in these areas. However, I present estimates for some elements of each and suggest alternative policies that might achieve the same goals at a lower social cost and with a smaller effect on the price level.

In the sections that follow I attempt to estimate the effects on the price level of various policies, using a consistent methodology. In each case, I calculate an initial (first-round) effect on the price of the affected good or service produced in the private sector. I then pass this price effect through to finished goods on a dollar-for-dollar basis and calculate its share of gross private domestic product. The relative importance of the price change is deduced from:

$$
\left[\frac{\Delta p_{i} q_{i}^{0}}{V A_{i}}\right]\left[\frac{V A_{i}}{V_{p}}\right]=\frac{\Delta P_{p}}{P_{p}},
$$


where $p_{i}$ is the price of output in the $i$ th sector; $q_{i}^{0}$ is the initial output of the $i$ th sector; $V A_{i}$ is valued added in the $i$ th sector; $V_{p}$ is the value of private domestic product; and $P_{p}$ is the domestic private deflator. I essentially calculate a Laspeyres index of the effect of various microeconomic policies on the price level. In only a few cases are substitution or ownprice effects computed.

I specifically avoid estimating any effects from these changes in the price level throughout the economy over time because there is no general consensus about the appropriate structure of wage-price equations in a macroeconomic model. It remains an open question whether prices affect wages through their influence on workers' expectations, through increases in the nominal marginal-value product of labor, or through escalator provisions. ${ }^{1}$ In fact, whether such a feedback between prices and wages exists at all is a subject of debate. ${ }^{2}$ In another paper in this volume George Perry provides new insight on this question, and concludes that there is some evidence of a price-wage effect in recent U.S. wage behavior. $\mathrm{He}$ argues for government cost-cutting measures as an important component of a comprehensive anti-inflation policy.

\section{Social Security}

The 1977 amendments to the Social Security Act were designed primarily to place the old age and survivors, disability, and health insurance (OASDHI) trust funds in a more solvent position. Except for health insurance, these funds were running large deficits in 1977. The deficits were projected to grow substantially in the next few years, in part because of the rapidly rising benefit levels and the increasing cost of disability benefits. To amend the act, the Congress could choose among raising the payroll tax rates, increasing the taxable wage base, or tapping general revenue for the trust funds. Moreover, if it chose to increase payroll taxes, it could increase employee contributions, employer contributions, or both. The Senate bill and the administration's proposal would have placed more of the burden on employers, but the final legislation more nearly paralleled

1. See Robert J. Gordon, "Inflation in Recession and Recovery," BPEA, 1:1971, pp. 105-58.

2. See Robert E. Hall, "The Process of Inflation in the Labor Market," BPEA, 2:1974, pp. 343-93. 
Table 1. Effect of the Social Security Revisions of 1977 on the Tax Rate and on the Taxable Wage Base, 1978-81

\begin{tabular}{|c|c|c|c|c|c|c|c|}
\hline \multirow[b]{2}{*}{ Year } & \multicolumn{3}{|c|}{$O A S D H I^{2}$ tax rate (percent) } & \multicolumn{3}{|c|}{ Taxable wage base (dollars) } & \multirow{2}{*}{$\begin{array}{c}\text { Total } \\
\text { cost of } \\
\text { revisions } \\
\text { (billions } \\
\text { of dollars) }\end{array}$} \\
\hline & Old law & New law & Change & Old law & New law & Change & \\
\hline 1978 & 6.05 & 6.05 & 0 & 17,700 & 17,700 & 0 & $\ldots$ \\
\hline 1979 & 6.05 & 6.13 & 0.08 & 18,900 & 22,900 & 4,000 & 6.4 \\
\hline 1980 & 6.05 & 6.13 & 0.08 & 20,400 & 25,900 & 5,500 & 9.4 \\
\hline 1981 & 6.30 & 6.65 & 0.35 & 21,900 & 29,700 & 7,800 & 18.4 \\
\hline
\end{tabular}

Source: Summary of the Conference Agreement on H.R. 9346: The Social Security Amendments of 1977 House Committee on Ways and Means, 95:1, WMCP: 95-61 (Government Printing Office, 1977).

a. Old age and survivors, disability, and health insurance.

the House version of the amendments, which required equal increases in employer and employee taxes.

It is reasonable to assume that employer contributions are reflected in product prices because they raise the total costs of compensating workers and thus unit labor costs. Employee taxes are simply a mildly regressive form of income taxation, which reduce employees' after-tax incomes. ${ }^{3}$ Placing less emphasis on employer contributions and more on employee taxes or general revenue financing is therefore likely to have more beneficial effects on price levels in the short run if labor supply is price inelastic.

The final bill enacted by the Congress, which delayed the increases until 1979 and raised employee and employer taxes equally, is among the less inflationary choices it could have made from the major proposals before it. The changes in the tax rates and the new ceilings for the income base are shown in table 1 . The total cost of these changes in terms of additional contributions to OASDHI is $\$ 6.4$ billion in $1979, \$ 9.4$ billion in 1980 , and $\$ 13.4$ billion in 1981 .

At present there is growing support for utilizing general revenue financing of the disability and health programs. In 1977, tax receipts for these two programs totaled $\$ 25.7$ billion. ${ }^{4}$ It has been argued that health insurance differs from old age and survivors insurance and disability insur-

3. However, Gordon, in "Inflation in Recession and Recovery," p. 121, finds that about one-seventh of employee direct taxes are shifted forward by workers.

4. Background Materials for Hearings on Social Security, Subcommittee on Social Security of the House Committee on Ways and Means, 95:1, WMCP: 95-40 (GPO, 1977), p. 3. 
ance because it does not pay benefits in proportion to a worker's past contributions and because benefits are not based on this wage experience. Thus, severing health insurance funds from payroll-tax funding would not impair the structure of the old age retirement system in social security. However, general revenue financing of disability insurance would create problems of justifying current eligibility requirements and of distinguishing it from the supplemental security income program, which provides benefits to the elderly, blind, and disabled. If the disability and health insurance contributions from employees and employers were replaced by general revenue financing-as specified in H.R. 10754, which is now being debated-the employer contributions would decline by approximately $\$ 14.6$ billion in fiscal year $1979 .{ }^{5}$ This would place downward pressure on unit labor costs and therefore prices, approximately offsetting the forthcoming employer tax increases in the OASDHI for 1979-81.

\section{Substitution of Direct for Indirect Taxes}

There can be little doubt that indirect taxes, such as general sales taxes, manufacturers' excise taxes, customs duties, and sumptuary taxes add directly to the price of the market basket of goods purchased by consumers. Moreover, changes in these taxes should be reflected in prices rather quickly. Okun has suggested that the federal government substitute direct taxation for sales taxes in order to achieve a one-time reduction in the price level. ${ }^{6}$ The potential effects on the price level of such a reduction are the most pronounced of any of the microeconomic proposals in this paper.

Most indirect taxes are levied at the state and local levels. In 1977, the federal government received only $\$ 17.4$ billion in excise taxes and $\$ 5.3$ billion in customs duties, a total of 6.1 percent of its tax receipts. ${ }^{7}$

At the state and local levels, sales taxes account for approximately 30 percent of all tax receipts, a total of $\$ 63.8$ billion in 1977. Some of these are sumptuary taxes that would not easily be given up for direct

5. Congressional Budget Office, "Comparison of the Impacts of a Cut in the Hospital Insurance and Disability Insurance Payroll Taxes with Those of the Administration's 1978 Tax Cut Proposal" (CBO, February 24, 1978; processed).

6. Arthur M. Okun, "The Great Stagflation Swamp," Challenge, vol. 20 (November/December 1977), pp. 6-13.

7. This includes social security contributions. 
federal transfers, but the general sales taxes might be a target. Obviously, any program to reimburse states for rescinding their sales taxes could place the federal government in the position of redistributing income across states. In 1976, Hawaii, for instance, collected sales taxes equal to 5.2 percent of its personal income while five states had no sales tax at all. Some minimum grant related to income could be paid to states without sales taxes. But in order to avoid major redistributions across states, the amount of sales tax for which federal grants were substituted would have to be limited.

For instance, if every state were to reduce its sales tax receipts by 1 percent of personal income originating in the state, with the revenue to be replaced by, say, half ( 0.5 percent) in state income tax and the remainder in federal revenues, there would be little if any redistribution across states. The federal tax system is mildly progressive in terms of personal income per capita. ${ }^{8}$ The substitution of federal revenues for state sales taxes would most likely result in an increase in the progressivity of the general tax structure.

How much of state sales taxes could be bought back? In 1976, all state and local sales taxes, including sumptuary taxes, amounted to 4.1 percent of personal income, or 5.2 percent of personal consumption expenditure. General state sales taxes were approximately one-half of this total. The distribution of the ratios of these general sales tax receipts to personal income is shown in table 2. Most states cluster between 0.015 and 0.030 . Therefore, a buyback of sales tax revenues up to 2 percent of personal income might be feasible without major redistributive effects. If the federal government offered 50 percent of each reduction up to 2 percent of personal income, the Treasury's bill would have been $\$ 12.4$ billion in $1976 .^{9}$ The total reduction in sales tax available from such a buyback would be an estimated $\$ 27.4$ billion in 1977 or 1.6 percent of gross

8. The personal income tax, which generates nearly one-half of federal government receipts, is related to personal income per capita as follows:

$$
\frac{\text { personal income tax }}{\text { personal income }}=0.0569+0.928 \times 10^{-5} \text { per capita income, }
$$

based on a 51-state cross-sectional regression using 1974 data. The elasticity of the tax rate with respect to personal income per capita is 0.46 at the point of means.

9. If the five states not utilizing a sales tax were given 1 percent of personal income as part of the program, the federal outlay would have risen by only $\$ 0.3$ billion to $\$ 12.7$ billion. 
Table 2. Distribution of Ratios of State General Sales Tax Revenue to Personal Income of the State, 1976

\begin{tabular}{lcc}
\hline $\begin{array}{c}\text { Ratio of sales tax } \\
\text { revenue to personal } \\
\text { income of the state }\end{array}$ & $\begin{array}{c}\text { Number of } \\
\text { states }\end{array}$ & $\begin{array}{c}\text { Share of total U.S. } \\
\text { personal income } \\
\text { (percent) }\end{array}$ \\
\hline 0 (no sales tax) & 5 & 2.32 \\
0.01 to 0.015 & 4 & 6.45 \\
0.015 to 0.02 & 13 & 41.57 \\
0.02 to 0.03 & 20 & 43.57 \\
0.03 to 0.04 & 4 & 1.90 \\
0.04 to 0.05 & 4 & 3.74 \\
0.05 and over & 1 & 0.45 \\
\hline
\end{tabular}

Sources: U.S. Bureau of the Census, Quarterly Summary of State and Local Tax Revenue, various issues, and Survey of Current Business, vol. 57 (August 1977).

a. General sales taxes and general gross receipts taxes. The latter are analogous to the former in their effects on the price level, but are levied on all business receipts rather than on retail sales.

domestic private product. ${ }^{10}$ If the federal government were to rescind its excise taxes in favor of an income tax, it might gain another 1.0 percent reduction in the private domestic deflator. In total, the federal government could potentially reduce indirect taxation by $\$ 44.8$ billion, based on 1977 revenues, yielding as much as a 2.7 percent reduction in the private domestic deflator.

Even if a substitution of direct for indirect taxes reduced the price level in the short run, problems in the long run could undermine this policy. In particular, a federal policy to buy back general sales taxes could be offset over time if the states selectively imposed indirect taxes-hotel occupancy taxes, licensing fees based on revenues, increases in sumptuary taxes, or specific excise taxes of other forms. Given the present apparent preference for indirect over direct taxes in many states, this difficulty cannot be ignored.

\section{Agriculture}

The past five years have provided some breathing space for the formulation of a rational policy for agriculture. After the Russian wheat purchases in 1972-73 and a subsequent reduction in world grain stocks,

10. Assuming that taxes on general sales and gross receipts increased at the same rate as personal consumption expenditures from 1976 to 1977. Survey of Current Business, vol. 58 (January 1978). 
prices of wheat and feed grains rose sharply. In 1973, the average price received by farmers for crops climbed 53.5 percent; and in 1974 it rose another 28.0 percent (see table 3 ). Resources were then rushed back into agriculture after farm incomes rose to record levels in 1973. As a result, for a brief period the emphasis in farm policy proposals shifted somewhat from price supports to price stabilization. ${ }^{11}$

INCOME SUPPORTS: THE CHOICE BETWEEN

DIRECT PAYMENTS AND PRICE ENHANCEMENT

Unfortunately, the respite was brief. The old problems in farm policy returned in 1977-78 after farm income declined from its 1973-74 plateau. The emphasis turned once again to raising farm incomes through price supports and direct government payments. A combination of political and budgetary pressures again imparted an inflationary bias to agricultural policy. While some progress was made toward establishing a rational mechanism for managing a price-stabilizing reserve program, the income-support policies adopted in 1977-78 have been unnecessarily inflationary with an emphasis on redistributing income to large farmers, rather than on supporting the small, family-owned farm.

The 1977-78 Policy Setting. In 1977, because of mounting pressure from farmers whose real income from farming (excluding capital gains) had fallen to approximately one-half of its 1973 level, Congress faced a choice of raising farm income through direct government payments or through price supports. It chose a little of each, raising the target prices for wheat and corn to $\$ 2.90$ and $\$ 2.00$ a bushel, respectively, and raising the loan rate for corn to $\$ 2.00$ while keeping the loan rate on wheat at $\$ 2.25$ a bushel. ${ }^{12}$ This reflected a decision to peg target prices on which government payments are calculated at or near the "cost of production," while keeping the loan rate for wheat (which effectively becomes a price-support floor) substantially below the level of estimated costs. When calculating the cost of production, however, Congress ac-

11. See, for example, Government and the Nation's Resources, Report of the National Commission on Supplies and Shortages (GPO, 1976), chap. 7.

12. The loan rate is the price at which the secretary of agriculture is authorized to make loans or purchases of the relevant crops. It therefore serves as a support price for commodity sales by all farmers. The target price is the price guaranteed to those farmers who participate in the program and is the basis for calculating direct government payments. 


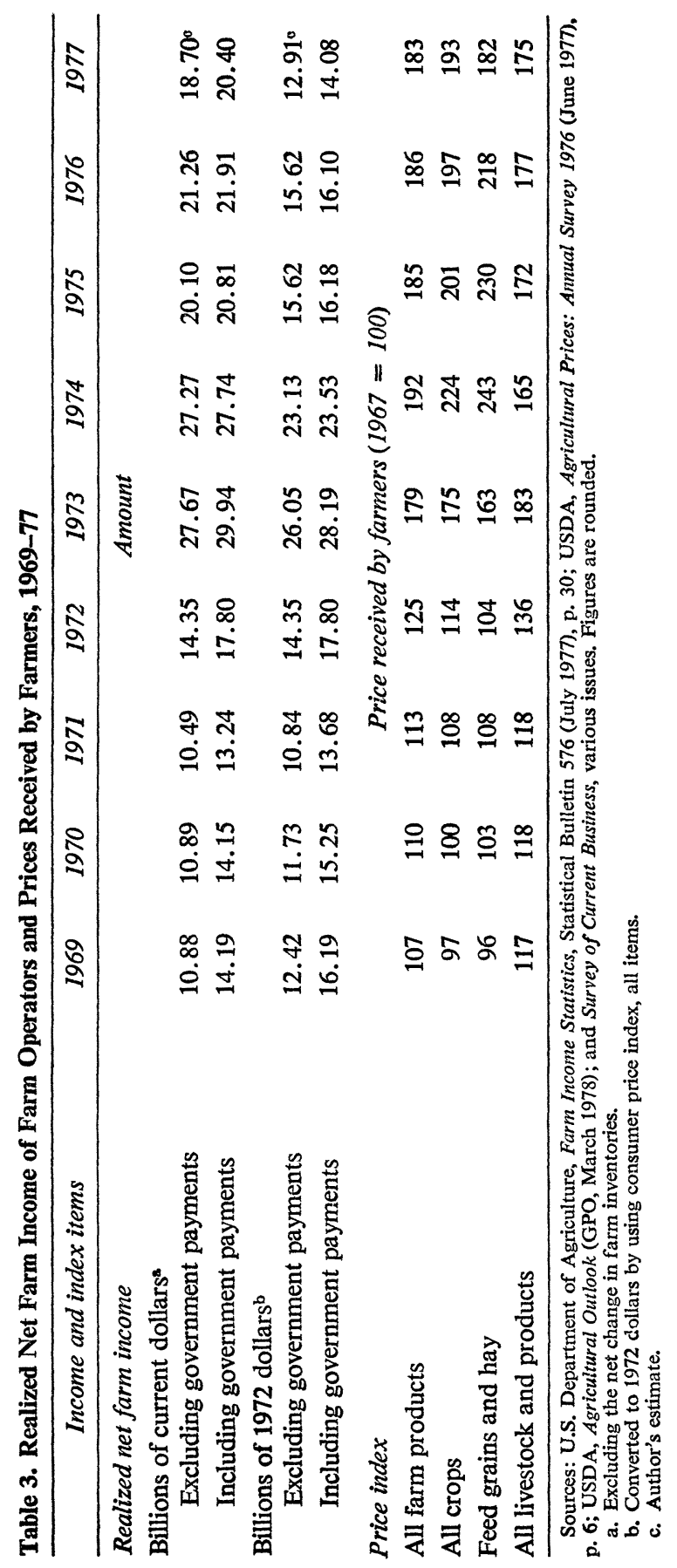


Table 4. Estimates of the Annual Costs to Consumers of 1977-78 Changes in Agriculture Policy

Millions of 1977 dollars

\begin{tabular}{|c|c|c|c|c|c|}
\hline \multicolumn{2}{|c|}{ Increase in price supports } & \multicolumn{2}{|c|}{ Set-asides ${ }^{b}$} & \multirow{2}{*}{$\begin{array}{l}\text { March } 1978 \\
\text { wheat, } \\
\text { feed grain, } \\
\text { and soybean } \\
\text { initiatives }\end{array}$} & \multirow[b]{2}{*}{ Total } \\
\hline Feed grains & Milk & Feed grains & Wheat & & \\
\hline 810 & 140 & 445 & 445 & 1,775 & 3,615 \\
\hline
\end{tabular}

Sources: Milk, Council on Wage and Price Stability; March 1978 wheat, feed grain, and soybean initiatives, USDA; other figures are author's estimates.

a. Assumes that the price of feed grains rises by 15 cents per bushel of corn equivalent.

b. Based on a participation rate for feed grains of 25 percent and an elasticity of demand of -0.5 ; for wheat, these figures are 75 percent and -0.5 , respectively.

c. Average of low and high yields.

cepted a methodology that included a return on the current value of land, which continued to rise despite declining farm income (see below). Thus, income supports were structured at least partially to ratify the inflationary expectations indicated in agricultural real estate markets.

The Food and Agriculture Act of 1977 created predictable problems for the administration. Feed grain stocks rose in response to the sharp increase in the loan rate while deficiency payments for wheat (the difference between the target price and the market price) placed considerable pressure on the Department of Agriculture budget. The administration's reaction was the use of acreage "set-asides." ${ }^{13}$ In early 1978, set-asides were announced of 10 percent of feed grain acreage and 20 percent of wheat acreage. These added nearly $\$ 900$ million to consumer costs in addition to the $\$ 800$ million from the increased loan rate on feed grains created by the 1977 act (see table 4). In March 1978, the administration announced further output-limiting policies, including payments for diverting feed grain and cotton acreage and additional incentives to graze wheat rather than to harvest it. The effect of the March initiatives was to increase the cost of farm commodities by $\$ 1.78$ billion annually. In addition, milk price supports were raised to add another $\$ 140$ million to annual food costs.

Why have these various forms of price enhancement been chosen for supporting farm incomes and stabilizing prices? If the objectives of agri-

13. The term "set-asides" refers to the requirement that farmers retire a specified percentage of their acreage during the crop year in order to participate in price support and disaster programs. 
cultural policy are price and income stability and the support of the small family farm, why not allocate government payments to the smaller, struggling farmer in periods of generally low farm income, while managing a commodity reserve program to stabilize prices? Part of the answer is, quite simply, that the apparent objective of current farm policy is to maintain the incomes of all farmers-particularly the large farm operators.

Agriculture is obviously not a sector dominated by small family farms. Since 1973, roughly the top 5 percent of farm operators have received between 55 and 60 percent of total cash receipts. These large farmers, with annual receipts of $\$ 100,000$ or more, averaged $\$ 93,748$ in net farm income in 1973, $\$ 9,406$ in off-farm income, and $\$ 94,116$ in capital gains (the accrued rise in value of farm real estate), or a total of $\$ 197,270$ per operator (see table 5).

The decline in farm income from 1973 to 1976 (the most recent years for which detailed data are available) was most pronounced among large farmers. The farms with the largest sales in table 5 show the sharpest decline in total income, with or without capital gains. But despite this decline in fortune, farmers with annual receipts in excess of $\$ 40,000$ a year continued to earn healthy returns on their investment. The return on equity shown in table 5 is not adjusted for the opportunity cost of the operator's labor, but even if, say, $\$ 15,000$ a year were deducted from income for this purpose, the return would not fall below 16 percent for the two largest categories of farms. On the other hand, a similar allowance would reduce the return to a low level for smaller farmers. In short, the largest farmers continued to prosper in 1976 while returns on capital for the smaller farmers were much less satisfactory. But it was the decline in income for the large farmers that generated the impetus for the 1977-78 farm policy approved by Congress and the administration.

Alternative Mechanisms for Supporting Farmers' Incomes. In 1977, Congress could have chosen to increase farm incomes by relying on deficiency payments, price supports, or direct payments scaled in proportion to the perceived economic needs of different farm operators. Direct payments, however, whether in the form of deficiency payments or other mechanisms, are so visible that Congress feels it must impose ceilings on the level of payments per farm. In the 1977 act these ceilings vary from $\$ 40,000$ to $\$ 52,250$ a year, depending on the crop. Previous experience with large expenditures on direct payments to farmers demonstrates that large farmers have obtained a major share of the payments, but they have 


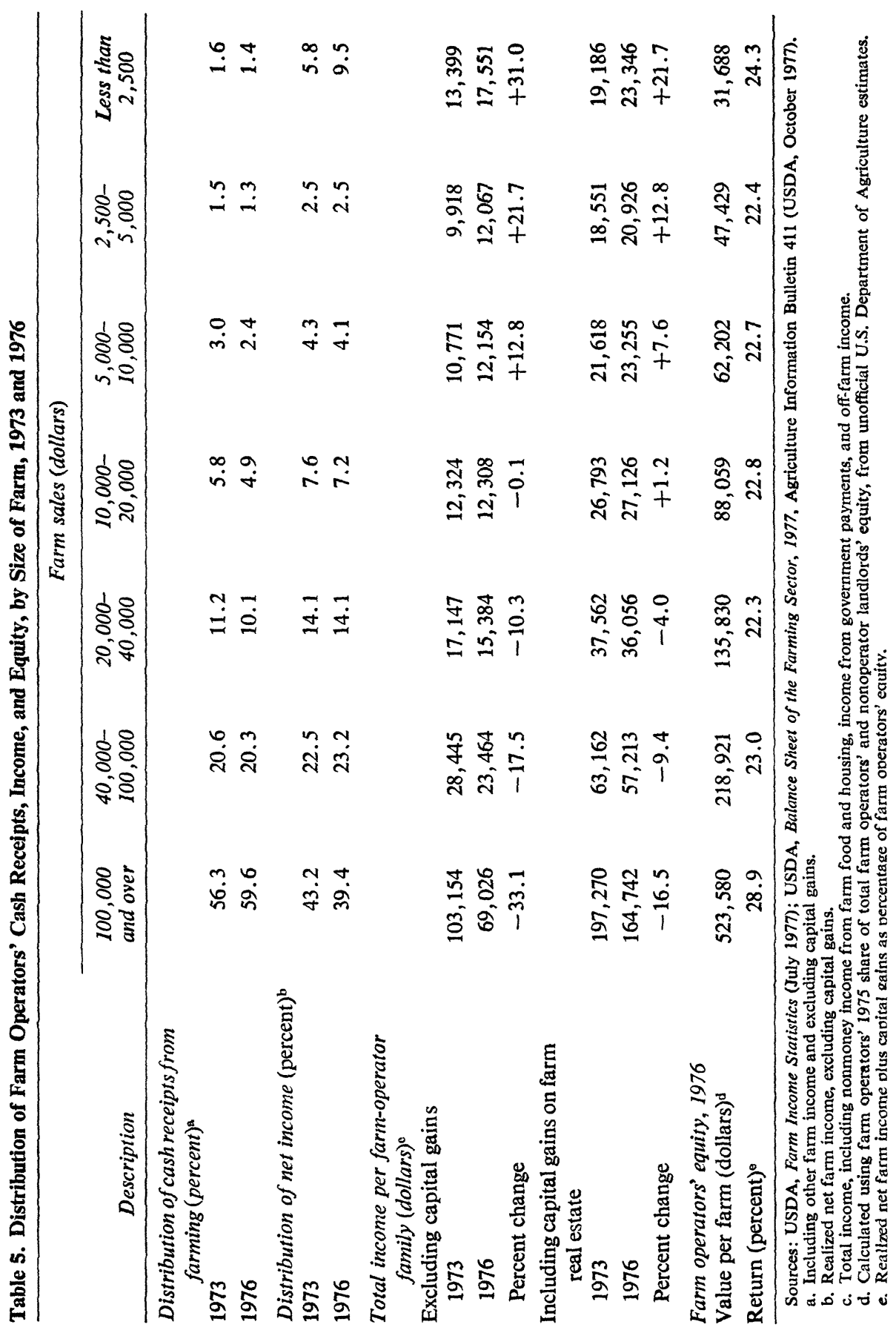


Table 6. Returns per Farm from Alternative Hypothetical Policies for Distributing \$4.4 Billion to Farmers, by Size of Farm

1976 dollars

\begin{tabular}{cccc}
\hline & \multicolumn{3}{c}{ Alternative palicies } \\
\cline { 2 - 4 } Farm sales & $\begin{array}{c}\text { Target-price income } \\
\text { supports with 1970 } \\
\text { entevernment payments } \\
\text { distribution } \\
(B)\end{array}$ & $\begin{array}{c}\text { Income supports with } \\
\text { equal payments } \\
\text { distribution } \\
(C)\end{array}$ \\
\hline 100,000 or more & 16,842 & 8,567 & 1,577 \\
$40,000-100,000$ & 2,896 & 3,716 & 1,577 \\
$20,000-40,000$ & 1,382 & 2,346 & 1,577 \\
$10,000-20,000$ & 711 & 1,585 & 1,577 \\
$5,000-10,000$ & 353 & 918 & 1,577 \\
$2,500-5,000$ & 182 & 553 & 1,577 \\
Less than 2,500 & 57 & 217 & 1,577 \\
\hline
\end{tabular}

Source: USDA, Farm Income Statistics (July 1977).

not enjoyed payments in proportion to their share of total receipts. In 1969-71, for example, the top 8 percent of farmers received approximately one-third of all direct payments from the government; their farms received more than 50 percent of all cash receipts from farming.

To compare the distributional effects of alternative mechanisms for supporting farmers' incomes, I assume that Senator Talmadge's objectives represent the 1978 consensus in the Congress. ${ }^{14}$ His initial proposal would have increased domestic farm commodity marketings by an estimated $\$ 4.38$ billion, compared to the prices that could have been expected without set-asides. This is enough to restore total real farm income to more than its relatively high 1972 rate. Policy A in table 6 assumes that a pure price-enhancing set-aside policy will raise farmers' incomes in proportion to their 1976 gross cash receipts. A second alternative is a policy that would distribute income support payments in the same relative proportions as those that occurred in 1970 when there were high price supports (policy $\mathrm{B}$ ); a third is one that would distribute $\$ 4.38$ billion equally across all farms (policy $\mathrm{C}$ ). The results show that a price-enhancement strategy greatly benefits the farmers earning more than $\$ 40,000$ at the expense of virtually all the others. The 1970 pattern of price-support payments would give farmers with sales in excess of $\$ 20,000$ a year (1976 dollars) more than an equiproportional share of the $\$ 4.38$ billion.

14. Emergency Agricultural Act of 1978, S. Rept. 95-699, $95: 2$ (GPO, 1978). 
Thus, a direct payment scheme, using either income-support payments subject to a ceiling or an equal payment per farm, would benefit the small farmer considerably relative to a price-enhancement strategy. Moreover, the direct payments would not translate directly into price-level effects as would a commodity price-enhancing strategy. The combination of high loan rates and acreage set-asides is not only inflationary but is also designed to convey most of the benefits to large farmers who continue to enjoy large average returns on their investments.

Land Values and the Cost of Production. Given the tendency of Congress to use price enhancement as a means of redistributing income to farmers, it is unfortunate that it has now settled on a standard based on cost of production for setting target prices and, indirectly, loan rates. These estimates of the cost of production include a 3.5 percent return on the current value of land, which has risen sharply despite declining farm income.

Throughout the 1950s and 1960s, the value of cropland and dairyland climbed steadily. This increase followed a rise in net farm income with a short lag. In the 1970s, land values soared in response to higher farm prices and, therefore, higher farm incomes. However, when farm incomes began to decline in 1974, the price of land continued to rise. Predictions of 1972-76 land values were based on equations that estimated the effect of current and lagged net income on land values for 1955-71. The result was underestimation for 1974,1975 , and especially 1976 (table 7). ${ }^{15}$ Actual land values in Iowa and Kansas approximately doubled between 1972 and 1976, while realized net income receded roughly to its real 1968-69 levels. Farmers were apparently expecting further income gains in the near future, perhaps from government initiatives.

\section{PRICE STABILIZATION}

While agriculture is a competitive sector of the economy, not necessarily subject to the downward price rigidity observed in many labor and product markets, there are major reasons why government policies are needed to stabilize food prices at some cost to economic efficiency. Food prices comprise a large share of the cost of living and may have major

15. Kansas, Iowa, and Wisconsin were chosen as typical wheat, corn, and dairy farming states, respectively. 
Table 7. Actual and Predicted Values of Farm Land in Iowa, Kansas, and Wisconsin, 1972-76a

Indexes of average value per acre $(1967=100)$

\begin{tabular}{|c|c|c|c|c|c|c|}
\hline \multirow[b]{2}{*}{ Year } & \multicolumn{2}{|c|}{ Iowa } & \multicolumn{2}{|c|}{ Kansas } & \multicolumn{2}{|c|}{ Wisconsin } \\
\hline & Actual $^{\mathrm{b}}$ & Predicted & Actual $^{\mathrm{b}}$ & Predicted & Actual $^{\mathrm{b}}$ & Predicted \\
\hline 1972 & 122 & 118 & 118 & 130 & 148 & 138 \\
\hline 1973 & 141 & 169 & 137 & 160 & 179 & 165 \\
\hline 1974 & 189 & 168 & 178 & 159 & 214 & 167 \\
\hline 1975 & 234 & 230 & 211 & 152 & 240 & 174 \\
\hline 1976 & 294 & 126 & 235 & 125 & 271 & 159 \\
\hline
\end{tabular}

Sources: USDA, Farm Real Estate Market Developments, CD-77 and CD-82 (July 1973 and July 1977); and USDA, State Farm Income Statistics, Supplement to Statistical Bulletin 576 (September 1977).

a. Land values regressed on current and two-period lagged net income, 1955-71.

b. March of each year.

effects on wage and price escalation in other industries. ${ }^{16}$ In addition, government agricultural income support programs now contain features that may mean downward price inflexibility for farm commodities in future years. Sudden rises in agricultural prices are rather quickly translated into increased farm land values, which in turn increase the cost of production used to calculate support and target prices. Hence the inflationary cost of repeating the experience of 1972-73 would be enormous.

To argue that the government should stabilize farm prices does not mean that it can. It may be difficult to devise operational decision rules for government programs that are stabilizing in the presence of major exogenous shocks. Moreover, even if such policies were designed well, political forces may not allow them to operate to increase stability. ${ }^{17}$

On the other hand, there is a general consensus that private decisions do not always lead to the optimal level of agricultural stocks. There are two reasons for this: first, speculators will not hold stocks for the low probability of a large return because government policy will not permit them to realize market-clearing prices during periods of prospectively high returns and, second, private decisions fail to include the social cost

16. Food accounted for 23.7 percent of the consumer price index as of December 1976. Food accounts for 19.3 percent and 17.7 percent of the two new CPIs introduced in 1978.

17. During the 1970s, the volatility of the crude food and feedstuffs of the wholesale price index actually declined relative to other crude materials, despite the return to a less interventionist agriculture policy. 
of inflation. As a result, it behooves government to subsidize or to accumulate stocks to augment those held by private investors and speculators.

The Food and Agriculture Act of 1977 recognizes this need by requiring the establishment of programs both to encourage producer storage for wheat and feed grains and to promote U.S. participation in international reserve programs. U.S. reserves are to be stimulated by government loans, payments for storage ( $\$ 0.25$ a bushel, as set by the Department of Agriculture), and penalties for sales from these reserves in advance of reaching prescribed "trigger points" when sales could begin. These points are defined in the act to be between 140 percent and 160 percent of the loan rate for wheat and at appropriate levels for feed grains. Wheat is to be accumulated in this planned reserve up to a total of 300 million to 700 million bushels. The purpose of these reserves is to "promote the orderly marketing of [the] commodities." Lacking, however, are instructions to insulate the management of this reserve from political forces. ${ }^{18}$

Although the reserve program may resemble the Houthakker program for entering future markets to stabilize agricultural prices, it is at present little more than a stockpile program. ${ }^{19}$ Unanswered are questions concerning how the size of the stockpile should vary over time, when the secretary of agriculture should increase diversions through augmentation of storage payments, or when feed grains should be released from the reserve. ${ }^{20}$ Congress could easily change the operation of the stockpile during a period of rising wheat prices by simply raising the (nonbinding) loan rate to within 40 percent of the market price. Finally, the pressure of political forces may lead to short-run decisions that are more destabilizing than the usual cycle of support payments, loan rates, and acreage set-asides. ${ }^{21}$

18. An example of these forces was an administration decision in March 1978 to forgive interest payments after one year for grain placed in government-subsidized reserves. This decision appears to have been based not on an assessment of the optimal reserve, but simply on the political necessities of the moment.

19. A description of the Houthakker program appears in Hendrik S. Houthakker, Economic Policy for the Farm Sector (American Enterprise Institute, 1967), chap. 7.

20. The secretary has considerable discretion in setting the level of payments to producers for storing the grain.

21. An example of such political pressure is found in the administration's new agricultural policy initiatives of March 29, 1978. While arguing that farmers' incomes rose 15 percent over the previous year and grain prices increased over 30 percent, the initiatives announced plans to increase reserves considerably through a reduction in interest charges. 


\section{SUMMARY}

Declining real farm income has spawned a set of income support policies that are unduly inflationary because of the political necessity of directing the benefits toward large farmers. If the welfare of smaller farmers were the principal motivation behind $1977-78$ policies, direct government payments could have been utilized effectively with much less effect on the price level. A new policy of building farm-commodity reserves indicates progress in the drive to stabilize farm prices, but even this policy is impaired by the short-term political necessity to maintain farm incomes.

\section{Government Regulation}

It is useful for the purposes of discussion to divide federal government regulation into at least two categories: economic and social. Economic regulation is the general rate-setting or price-setting form of regulation that has long been in existence. While the ostensible purpose of such regulation is generally to restrict monopolistic control over price, it often leads to implicit cartelization of the regulated firms and to prices (or rates) that are in excess of the cost of service. In energy markets, however, much of the current regulation represents an attempt to transfer economic rents from producers to consumers while acknowledging a loss in economic efficiency.

During the past decade, social regulation-largely environmental, health, and safety regulation - has grown so rapidly that it challenges and perhaps surpasses the economic forms of regulation in its impact on prices and economic efficiency. It is in this newer area that the greatest opportunities lie for changing the government's effect on the price level because Congress has generally chosen to have it implemented through the mandating of cost-increasing methods of control. This choice is a pragmatic one, but it is rarely coupled with a requirement that the regulation be efficient.

\section{ECONOMIC REGULATION}

Of the government-regulated transportation, communications, energy, banking, and securities industries, only the transportation industry offers 
important opportunities for reforms that would decrease the price level. Current energy regulation reflects an attempt to restrain the upward adjustment of energy prices in the short run, although there is some evidence that the regulation of gas pipelines raises prices. ${ }^{22}$ Communications regulation is currently being reformed substantially through a variety of court tests and the inexorable progress of new technology. ${ }^{23}$ The securities industry is already being persuaded by the Securities and Exchange Commission to increase competition, and the effect of banking regulatory reform cannot easily be measured in terms of the price level.

In the transportation sector, reform would mean deregulation of entry and fare setting. A step in this direction has been taken in the KennedyCannon bill, which would provide greater fare flexibility and liberalize entry into the interstate airline industry. A similar approach is clearly possible for trucking, given the limited economies of scale in that industry. Finally, amending the current cabotage laws that restrict the coastal trade to vessels manned and built by U.S. labor would greatly reduce shipping costs in the coastal trade for the maritime industry. In each of these transportation sectors, the need for deregulation is evident. In the absence of regulation, competitive forces would operate satisfactorily in each, and there would be little reduction in service to small communities or small shippers. Only in the case of the maritime industries could national security be used as an argument for continuing to maintain rates above market levels, and even in this market there are other, less expensive means for promoting the nation's security.

The prospective net savings in fares from deregulating the airlines, trucking, and the coastal maritime trade appear in table 8. These estimates, based on existing studies, are at best approximate and do not include a measure of deadweight loss nor reflect the shifts among modes of transportation that would occur. Full deregulation-a political impossibility-would lower transportation costs by at least $\$ 5$ billion and perhaps $\$ 10$ billion a year.

22. Stephen G. Breyer and Paul W. MacAvoy, Energy Regulation by the Federal Power Commission (Brookings Institution, 1974).

23. By this I do not mean that rewriting the Communications Act of 1934 or a government victory in United States vs. American Telephone \& Telegraph Company will not change the pace of deconcentration, but only that competition is virtually inevitable in the telecommunications industry. 
Table 8. Potential Price Effects from Deregulating Transportation Industries, 1976

\begin{tabular}{lccc}
\hline \multicolumn{1}{c}{ Industry } & $\begin{array}{c}\text { Total revenue } \\
\text { (billions of dollars) }\end{array}$ & $\begin{array}{c}\text { Price impact from } \\
\text { deregulation } \text { (percent) }\end{array}$ & $\begin{array}{c}\text { Potential annual savings } \\
\text { (billions of dollars) }\end{array}$ \\
\hline Airline & 16.8 & -20 to $-30^{\mathrm{a}}$ & 3.4 to 5.0 \\
Trucking & $26.0^{\mathrm{b}}$ & -7 to $-20^{\mathrm{b}}$ & 1.8 to 5.2 \\
Maritime $^{\mathrm{d}}$ & n.a. & n.a. & 0.10 to $0.15^{\circ}$ \\
\hline
\end{tabular}

Sources: U.S. Civil Aeronautics Board, Supplement to the Handbook of Airline Statistics, Covering 1975 and 1976 (GPO, 1977); and Interstate Commerce Commission, unpublished calculations. See also notes a, c, and e.

n.a. Not available.

a. Based on data in George W. Douglas and James C. Miller III, Economic Regulation of Domestic Air Transport: Theory and Policy (Brookings Institution, 1974), p. 90, and in Theodore E. Keeler, "Airline Regulation and Market Performance," Bell Journal of Economics, vol. 3 (Autumn 1972), pp. 399-424.

b. Motor carriers of property, classes $1,2,3$.

c. Based on data in Thomas Gale Moore, Freight Transportation Regulation: Surface Freight and the Interstate Commerce Commission (American Enterprise Institute, 1972) and various studies cited therein.

d. Cabotage laws.

e. Gerald R. Jantscher, Bread upon the Waters: Federal Aids to the Maritime Industries (Brookings Institution, 1975), chap. 5 .

\section{SOCIAL REGULATION}

The reform of social regulation may have important effects on the price level. While this type of regulation can and does bring substantial benefits to society, there is a need to provide the agencies responsible for its execution with an incentive to achieve these benefits at the lowest possible cost-an incentive that is currently lacking. A rather large number of regulatory authorities are entrusted with this newer type of regulation, including the Environmental Protection Agency, the Occupational Safety and Health Administration, the Food and Drug Administration, the Consumer Product Safety Commission, the Federal Aviation Administration, the National Highway Traffic Safety Administration, the Coast Guard, the Mining Enforcement and Safety Administration, the Department of the Interior, and the Forest Service of the Department of Agriculture.

Of all the agencies entrusted with social regulation listed above, the two having the greatest responsibilities across the breadth of the economy and the largest impact on business costs are the Occupational Safety and Health Administration and the Environmental Protection Agency. The prospective net social costs of their regulations is discussed below.

The Occupational Safety and Health Administration. There is no good source of the total prospective costs of OSHA's regulation. At best, the costs can be estimated for the regulations that have been promulgated since 1975 or those that have been proposed but not finally pro- 
Table 9. Prospective Annual Cost of Major Regulations Proposed or Promulgated by the Occupational Health and Safety Administration, 1974-77

\begin{tabular}{|c|c|c|c|c|}
\hline \multirow[b]{2}{*}{ Item regulated } & \multirow[b]{2}{*}{ Date proposed } & \multirow{2}{*}{$\begin{array}{c}\text { Number of } \\
\text { workers } \\
\text { protected }\end{array}$} & \multicolumn{2}{|c|}{ Annual cost $(1977 \text { dollars })^{\mathrm{a}}$} \\
\hline & & & $\begin{array}{c}\text { Total } \\
\text { (millions) }\end{array}$ & $\begin{array}{c}\text { Per protected } \\
\text { worker }\end{array}$ \\
\hline Noise & October 24, 1974 & 206,700 & $1,985.3^{\mathrm{b}}$ & $9,605^{b}$ \\
\hline Arsenic & January 21,1975 & 7,400 & 125.3 & 16,932 \\
\hline Coke ovens & July 31,1975 & 29,600 & 262.6 & 8,872 \\
\hline Sulfur dioxide & November 24, 1975 & 14,000 & 177.4 & 12,671 \\
\hline Lead & October 3,1975 & 5,200 & 363.4 & 69,885 \\
\hline Deep-sea diving & June 15, 1976 & 1,500 & 23.0 & 15,333 \\
\hline Acrylonitrile & January 17,1978 & 3,400 & 23.1 & 6,794 \\
\hline Benzene & May 27, 1977 & 191,000 & 503.6 & 2,637 \\
\hline All items & $\ldots$ & 458,800 & $3,463.7$ & 7,550 \\
\hline \multicolumn{5}{|l|}{ Addendum } \\
\hline Cotton dust & December 20, 1976 & $314,000^{c}$ & 717.5 & $2,285^{d}$ \\
\hline
\end{tabular}

Sources: Based on data in Occupational Safety and Health Administration, Dockets OSH-11A, OSH-37, H-017A, H-039, H-004, H-103, and H-052, respectively, for first six items and last item in the table; submission by the Council on Wage and Price Stability to OSHA, "Analysis of Proposed Benzene Standard," appendix, September 12, 1977, for benzene; unpublished data from the Council on Wage and Price Stability, for acrylonitrile.

a. Deflated using the implicit GNP deflator for producers' durable equipment from the quarter of proposal.

b. Assuming a $90 / 90$ standard (scale of dBA noise level), where the first number indicates the noise level for the initiation of engineering and administrative controls and the second number, the noise level for the use of hearing protectors.

c. Total employment, not the protected population.

d. Minimum.

mulgated. Table 9 provides a summary of items affected by major regulations, with the estimated annual cost and the number of employees to be protected for each. Most data are drawn from the inflation and economic impact analyses performed for OSHA.

An important measure of the impact of OSHA is the cost per protected worker. In four of the eight cases in which this measure can be calculated, the cost of the agency's proposed regulations exceeds total average earnings per worker in manufacturing. The principal reason for this enormous cost is the reliance on engineering controls rather than on work practices and personal protective equipment. Clearly, such costly regulationsif promulgated-will drastically change the industries affected because many will find it unprofitable to continue operation without major reductions in output.

In 1977 dollars, the prospective costs of the nine major regulations listed are $\$ 4.2$ billion a year -0.25 percent of the gross private product. Excluded are new regulations controlling toxic substances such as manda- 
tory labeling, which could add several billion dollars a year, and the agency's general carcinogen policy now under development.

In a recent article, Edward Denison estimated that in 1975 the total annual cost of the OSHA's regulation of the nonmining, nonresidential workplace was $\$ 972$ million, or 0.09 percent of the nonresidential net national product. ${ }^{24}$ Thus, the prospective costs of regulations listed in table 9 are more than four times Denison's estimates for 1975. The impact of this type of regulation will undoubtedly grow in the next few years.

Environmental Regulation. To calculate the prospective cost of environmental regulation in the next few years, a slightly different approach is taken. The Environmental Protection Agency has recognized that its regulations governing air and water will have the greatest impact on six industries: electric power generation, petroleum refining, steel, paper, copper, and chemicals. As a result, the agency has funded analyses of the total cost of controls for each of these industries. Only the study on the chemicals industry is incomplete as of this writing.

It is estimated that the prospective cost of the first phase of environmental regulations, excluding new regulations promulgated in response to 1977 legislation, will be $\$ 7.83$ billion a year in 1977 dollars (see table 10). If enforcement of these regulations were begun in a timely fashion, these costs, except for utilities, would have been incurred by 1977 and each year thereafter. By 1983 (1985 for utilities), these costs will rise to $\$ 13.81$ billion a year, excluding new regulations under study currently at the Environmental Protection Agency. ${ }^{25}$

These estimates of environmental costs for five major industries, combined with earlier work on the industrial distribution of air control and water control (best-practicable-technology standard, or BPT) outlays, may be used to calculate a prospective total annual cost of air and water pollution controls in the near term (1977 standards) and in the mid1980s. Assuming that the five industries contribute to total future costs in the same proportion as they do to current air and BPT water control costs, the prospective cost for air and water pollution control in the nonfarm business sector of the economy, excluding the cost of controlling

24. Edward F. Denison, "Effects of Selected Changes in the Institutional and Human Environment upon Output per Unit of Input," Survey of Current Business, vol. 58 (January 1978), pp. 21-44.

25. These include new standards for sulfur dioxide emissions from new sources, revision of ambient air quality standards, a new lead standard, revision of state implementation plans under the Clean Air Act, and new approaches to carcinogens. 
Table 10. Prospective Annual Cost of Environmental Controls for Legislation in Effect in 1976, Five Major Industries and All Industries, 1977 and 1983

Billions of 1977 dollars

\begin{tabular}{lcc}
\multicolumn{1}{c}{ Industry } & 1977 & 1983 \\
\hline Electric utility & $4.28^{\mathrm{b}}$ & $7.13^{\mathrm{c}}$ \\
Petroleum refining & 1.79 & 2.96 \\
Steel & 0.90 & 2.36 \\
Pulp and paper & 0.69 & 1.07 \\
Copper & 0.17 & 0.29 \\
Total & 7.83 & 13.81 \\
All industries & 25.34 & 44.69 \\
\hline
\end{tabular}

Sources: Estimated using U.S. Environmental Protection Agency, Office of Planning and Evaluation, "Economic and Financial Impacts of Federal Air and Water Pollution Controls of the Electric Utility Industry: Technical Report," EPA-230/3-76-013 (EPA, May 1976; processed); ibid., "Economic Impact of EPA's Regulations on the Petroleum Refining Industry," pt. 1, EPA-230/3/76-004 (EPA, April 1976; processed); Temple, Barker \& Sloane, Inc., "Analysis of Economic Effects of Environmental Regulations on the Integrated Iron and Steel Industry," vol. 1, EPA-230/3-77-015 (EPA, July 1977; processed); Arthur D. Little, Inc., "Bconomic Impacts of Pulp and Paper Industry Compliance with Environmental Regulations," vol. 1 (ADL, nd; processed; available through National Technical Information Service); ADL, "Economic Impact of Environmental Regulations on the United States Copper Industry," submitted to EPA (ADL, January 1978; processed); all industries, estimated from L. P. Gianessi, H. M. Peskin, and E. Wolff, "The Distributional Effects of the Uniform Air Pollution Policy in the United States," discussion paper D-5 (Resources for the Future, March 1977; processed), table 1, and L. P. Gianessi and H. M. Peskin, "The Cost to Industries of Meeting the 1977 Provisions of the Water Pollution Control Amendments of 1972," Contract No. 68-01-2817 (National Bureau of Economic Research, January 1976; processed).

a. Assumes full enforcement of all control legislation in effect in 1976. Costs adjusted using implicit GNP deflator for producers' durable equipment.

b. 1980 .

c. 1985 .

nonbusiness automobiles, is $\$ 25.34$ billion annually in the near term and $\$ 44.69$ billion a year by the mid-1980s. This is decidedly higher than the latest forecast of the Council on Environmental Quality for private costs of water and stationary air-quality regulation in 1985. In 1977 dollars, the council's estimate is $\$ 24.4$ billion in annual outlays in addition to those costs that would be borne without environmental regulation, and $\$ 34.9$ billion for all costs, whether or not they are in response to regulation. ${ }^{26}$

The above cost estimates exclude mobile sources, although the costs of controlling these sources now exceed those of stationary ones. In addition, these estimates ignore the costs of public water treatment and solid waste management because these are largely funded from general revenues with little effect on the price level.

Denison's estimate of the incremental cost of pollution abatement to nonresidential business mandated by the Environmental Protection

26. Environmental Quality-1977, The Eighth Annual Report of the Council on Environmental Quality (December 1977). 
Agency and state and local authorities is $\$ 9.55$ billion for 1975 , or approximately 0.7 percent of the net national product. ${ }^{27}$ This is a remarkably small total, given the pervasiveness of environmental regulation and the above estimates. In part, its small size indicates that many enforcement deadlines for environmental standards had not yet been reached in 1975. As table 10 suggests, these outlays will rise substantially in the next few years.

In summary, the prospective costs of environmental, health, and safety regulation will undoubtedly be large by the middle of the next decade. In many cases, such as control of air emissions from stationary sources, the costs may be substantially less than the prospective benefits, but in others - such as control of mobile sources-the evidence is far less conclusive. Regardless of the merit of the strictness of environmental or social controls, the experience of OSHA and the Environmental Protection Agency in setting standards suggests that there may be considerable room for reducing the cost of achieving the desired benefit levels. A few examples of recent or pending decisions will serve to highlight the absence of costeffectiveness in regulatory decisionmaking in various agencies.

Occupational Exposure to Coke-Oven Emissions. The standards promulgated by OSHA for coke-oven emissions are illustrative of the tendency for regulators to specify engineering standards (mandating the installation of given equipment) rather than performance standards (specifying the maximum allowed rate of exposure to the risk in question). In this case, OSHA opted for specific engineering controls instead of a combination of work practices and personal protective devices (respirators). The latter strategy would have been much less expensive but less easily enforced. Respirators are uncomfortable and are therefore likely to be ignored by many workers for substantial periods of time. As a result, OSHA requires them only when the engineering controls fail to achieve a desired maximum emissions level. If they were required for all workers, regardless of the effectiveness of the engineering controls, greater protection would be afforded the exposed population. On the other hand, if they were required as a substitute for the engineering controls, the annual cost of the standard would have been substantially less than $\$ 8,900$ per protected worker.

Segregated Ballast. The Carter administration proposed in April 1977

27. This is an "incremental" cost over and above the expenditures firms would have undertaken in the absence of recent environmental legislation. 
that all tankers serving the U.S. market should be required to segregate ballast from cargo. This regulation would apply to both existing and new ships. The cost of retrofitting ships and the effect of reducing capacity because of that retrofitting will be an estimated $\$ 360$ million a year based on the administration's initial proposal. This cost would be incurred despite the availability of other less expensive techniques for controlling marine pollution.

National Forest Policy. The current timber policy of the Department of Agriculture has led to a substantial underutilization of the national forests. While the department is required by law to limit the number of trees that can be cut from these national forests to a level no greater than the long-run sustainable yield, temporary increases could be permitted in the cut of mature trees without any reduction in the long-run yield from younger, faster growing ones. However, environmental pressures have succeeded in preventing the Forest Service from increasing the cut in this manner. As a result, the supply of timber from national forests has not grown; it actually decreased by approximately 17 percent between 1970 and $1976 .{ }^{28}$ It is difficult to estimate how much of an increase in the cut from national forests could be both economically feasible and consistent with the current timber policy requiring a nondeclining yield. Much of the underutilized timber is in wilderness areas that are expensive to exploit and valuable as environmental preserves. If the cut could be increased by at least 10 percent without violating the 1976 National Forest Management Act (and without exceeding the 1969 cut), the price of timber would decline by at least 3 percent, assuming a demand elasticity of -0.5 , a 1.8 percent decline in private forest output, and a decrease in net imports of 0.4 percent. The impact would be to lower timber costs by approximately $\$ 300$ million annually.

Passive Restraint Systems for Automobiles. ${ }^{29}$ In 1977, the secretary of transportation announced a decision to require passive restraint systems for all front-seat positions on all new passenger cars, beginning with selected size classes in 1981 . The decision, while not as costly as one that mandates air bags, will require at least passive safety belts at about $\$ 25$ per car more than present belt systems. Alternatively, the Department of

28. These and the following estimates are drawn from the Council on Wage and Price Stability, Lumber Prices and the Lumber Products Industry, Interim Report (The Council, October 1977).

29. Air bags or passive safety belts. 
Transportation has estimated the cost of air bags to be between $\$ 100$ and $\$ 200$ more than the present belt systems. The total cost of the standard, therefore, is between $\$ 250$ million and $\$ 2$ billion a year. ${ }^{30}$ This standard was adopted despite evidence that safety belts were the most effective safety devices. If air bags diminish seat belt usage, the standard could increase highway fatalities.

"Rolled-in" Pricing of Natural Gas. The Federal Power Commission (now the Federal Energy Regulatory Commission) has issued initial rulings that imports of liquid natural gas may be rolled in with gas purchased domestically by pipelines so that the imported liquid natural gas does not reach final buyers at its true incremental acquisition price. The practical effect of this policy in a world in which domestic field prices are being regulated and customers are allocated the gas at less than market equilibrium prices is to transfer the rents from domestic owners of "old" natural gas to foreign producers or their agents. At present, it is difficult to place a cost on the policy of rolling in imported liquid natural gas at prices as high as $\$ 5.27$ per thousand cubic feet because the full extent of importation has not yet been realized; approximately 5 percent of natural gas is now imported. The potential cost of this policy is equal to the difference between the full equilibrium market value of domestic gas and the regulated cost of this gas. ${ }^{31}$ This difference is roughly $\$ 36$ billion per year, or 2.2 percent of the gross private domestic product in $1977 . .^{32}$

Multiple-Point Source Regulation: Guidelines for Iron and Steel Effluents. In the absence of sophisticated monitoring techniques, the Environmental Protection Agency has promulgated regulations for both water and air emissions based on engineering performance standards for equipment at each "source" in an industrial complex. Because the goal of environmental controls is to reduce total emissions or discharges per unit of time, it would seem more efficient to specify emission levels (or pollution taxes) for entire industrial facilities and even to allow trading of rights between different companies in the same area.

30. This cost would not enter the consumer price index because the restraint systems are considered quality improvements by the Bureau of Labor Statistics. To the extent that air bags reduce the severity of accidents, they should reduce insurance rates as well.

31. The equilibrium market value of gas is assumed to be equal to $\$ 2.40$ per thousand cubic feet.

32. Estimate based on data on prices and consumption in U.S. Department of Energy, Monthly Energy Review, various issues. 
The effect of the Environmental Protection Agency's detailed approach to regulation may be illustrated by the guidelines for iron and steel effluents proposed in March 1976. A study by the Council on Wage and Price Stability found that the standards for removal of total suspended solids proposed for 1983 produced incremental costs for meeting the single standard that were nine times as high for some parts of a plant's operation as for other parts. ${ }^{33}$ Clearly, a rational management, if allowed to minimize its costs in meeting an overall standard for an entire plant, would not allow the incremental costs to diverge so widely across various point sources. The same environmental cleanliness could thus be purchased at much lower costs if the Environmental Protection Agency would set standards for an entire plant as a unit.

Mandate for Best-Available-Control Technology in the Clean Air Act Amendments of 1977. In 1977, the Congress amended the Clean Air Act in several ways, one of which was to require the Environmental Protection Agency to mandate the "reasonably best available control technology" for emissions from all new stationary sources. ${ }^{34}$ This requirement places the emphasis on the reduction in pollution, particularly sulfur, rather than on the level of sulfur emissions. Hence, it requires the Environmental Protection Agency to mandate the use of scrubbing (or another specific technology) in combination with virtually any type of coal. This means that a utility no longer will be given the choice between burning low-sulfur coal or scrubbing the stack gases from combustion of higher-sulfur coals. The goal of those proposing the amendment was to stimulate the demand for eastern and midwestern coal because previous standards for new sources (1.2 lbs of sulfur per million Btu) would lead to the importation of cheap, low-Btu, low-sulfur coal from western mining regions to north-central locations. The Environmental Protection Agency has not yet issued its standards for new sources to conform with this requirement, but it is likely to cost four to eight times as much per incremental ton of sulfur removed as the cost in the sulfuric acid or nonferrous metals industries. The additional costs may therefore be between $\$ 1$ billion and $\$ 2$ billion annually.

33. See "Effluent Guidelines and Standards for Existing and New Sources in the Iron and Steel Manufacturing Point Source Category 40 C.F.R. 420," Comments of the Council on Wage and Price Stability before the Environmental Protection Agency (June 24, 1976; processed).

34. 91 Stat. 712. 


\section{IMPROVING REGULATION: A STRUCTURAL APPROACH}

The preceding examples of regulation illustrate prospective policies with potentially important impacts on the price level. In many cases, they reflect political decisions of regulators who have little incentive to equate incremental social costs to prospective benefits. Allowing or disallowing a rate increase does not affect a regulator's budget. Similarly, the costeffectiveness of social regulation is not systematically measured by the agencies promulgating the regulations, by the Office of Management and Budget, or by the Congress. As a result, administrators have little incentive to spend their agencies' scarce resources in the pursuit of economically efficient regulation. Invoking public health and safety is often sufficient to blunt the thrust of any critic who claims that the costs are too large for the benefits derived.

Faced with these obvious problems, the Ford and Carter administrations have attempted to require economic analysis from executive department regulatory agencies. President Ford launched the "inflation impact" program in November 1974. Under this program, each agency within the executive branch was required to prepare an economic assessment of the effects of major regulations-generally those with an aggregate impact of $\$ 100$ million for one year or $\$ 150$ million for two years. These analyses were intended to serve as a check on the efficiency of the regulations, but they did not achieve the planned result. Many agencies virtually ignored the program, while others perfunctorily had contractors perform the studies. ${ }^{35}$ These analyses influenced agency decisionmaking in only a few cases. Moreover, they became the source of heated debate concerning the intent of the program. A congressional report suggested that cost-benefit estimates required in such analyses are counterproductive because they are likely to be biased and impossible to undertake with precision. $^{36}$

35. For details of agency compliance, see the joint evaluation of the inflation impact program by the Council on Wage and Price Stability and the Office of Management and Budget, "An Evaluation of the Inflation Impact Statement Program," prepared for the Economic Policy Board (December 7, 1976; processed).

36. Federal Regulation and Regulatory Reform, Report by the Subcommittee on Oversight and Investigations of the House Committee on Interstate and Foreign Commerce, 94:2 (GPO, 1976). 
In this climate of congressional hostility to the cost-benefit approach, regulators have not been pressing the frontiers of applied economic analysis. Nevertheless, the Carter administration has announced a policy of requiring economic impact analyses from each agency for major decisions. Less emphasis is placed on the benefit side of cost-benefit analysis, but the intent is similar to that of the inflation-impact program. Because administrators of the important agencies will continue to have little incentive to perform these analyses well, this policy is not likely to meet the goals set for it.

How could government regulation of health, safety, and environment be made more efficient and thus less "inflationary"? The only approach that will work must tie the economic efficiency of regulations to the agency's budget constraint. This could be done either by reversing the ownership of property rights in question or by developing a new "shadow" budget for each agency, by which it is limited to a specified amount of society's resources each year.

Reversing the Ownership of Property Rights. The suggestions that polluters should be compensated for reducing pollution or paid to increase worker or product safety are not new ones. Whether such mechanisms could work has been discussed at length by Coase and others. ${ }^{37}$ As long as there are multiple sources of each externality in a given location, there could be a "market" with a regulatory agency as buyer-representing workers, residents, or consumers-and the producers of the externality as sellers. Presumably such a market would only require the buyer to calculate the clients' reservation price for the externality and to submit a bid for it at that price. If, however, there were few sellers of the externality in a location, the reversal of property rights might not work efficiently because of the possibility of monopolistic control.

Reversing property rights creates yet another problem. The supply of the offensive externality varies with the ownership of the property right. If the government owned the rights, for example, any new emitter of pollution would have to purchase those rights from it at a specified fee or under specified conditions or regulation. If the ownership resided with owners or lessees of land adjacent to the water or air in question, the supply of the undesired externality would become potentially unlimited.

37. R. H. Coase, "The Problem of Social Cost," Journal of Law and Economics, vol. 3 (October 1960), pp. 1-44. 
Threats to pollute could be increased without limit in order to gain revenues from the public authority.

A solution to this problem is to pay the polluters for permanent reductions in their discharge rate and use this payment rate as the tax rate for new sources. The partial reversal of property rights would mean that large budget outlays would have to be made by the regulatory authorities to reduce these externalities. Increases in the price of pollution would mean that pollution from new sources would be less attractive, but only at a cost to the regulator. Moreover, the regulator would now search for the strategy with the lowest cost for reducing the externality to maximize his achievements for any given budget.

Use of Shadow Budgets. The most practical possibility for confronting regulators with the costs of their actions would be to construct a shadow budget to cover the resources that the agency requires private agents to consume in the pursuit of the regulatory goal. An agency such as the Office of Management and Budget would have to administer such a system, but Congress could specify the size of the budgets for each agency or even each program. Administrators would not be told how to value the benefits of the dangers they presumably would reduce. Instead, there would be a limitation on the cost that they could impose on firms in a given year; their function would then be to maximize the benefits of their regulations subject to that limitation. These cost limitations would be publicized each year in the budget message and would therefore be more visible to the public, which, in turn, would be less likely to assume that regulatory costs are minimal.

The administration of such a system would not be easy, for someone would have to arbitrate the differences in the estimates of costs. These estimates probably would be undertaken by a competent staff close to the administrator of each agency because his total accomplishments would be limited by the magnitude of the costs of each regulation. An inefficient choice of regulations in one area would reduce his ability to promulgate regulations in others. In addition, there would be much greater interest in equating the incremental costs of controlling the same externality from different sources. Because these costs are difficult to estimate ex ante, there should be provisions for carrying back and carrying forward cost limitations in each budget. Costs could be estimated ex post, and the difference between the estimates could be deducted from the budget 
of the current year in the case of cost overruns or added to the budget in the case of earlier overestimates of costs. A discount rate could even be applied to such carryovers.

\section{FUTURE PROSPECTS}

No proposal that fails to alter the incentives of regulators will cause the protectors of the environment, the guardians of carcinogens, or the preventers of highway deaths to take economics as seriously as they should. Present incentives, combined with imprecise statutory language about economic efficacy, cause administrators to be concerned with major, localized employment reductions (often through plant closings) rather than with other economic effects. A price mechanism or a budgetary process would change this system of incentives and have potentially salutary effects on the price level.

\section{Foreign Trade Restrictions}

A classic example of government support of prices to redistribute income can be found in trade policy. It allows the government to protect an industry and its employees without direct budget outlays. Protectionism is likely to be sought and granted during periods of economic recession or declining comparative advantage for individual industries. It is not surprising, therefore, that since 1975 there have been numerous new protectionist pleas from industries such as steel, textiles, footwear, electronics, copper, and zinc. Many of these pleas have led to successful rulings in cases presented before the International Trade Commission.

The costs and benefits of the major examples of trade relief granted by the commission or the administration from 1975 to 1977 are indicated in table 11. Each of these actions-tariffs, quotas, or minimum requirements for import prices-generates significant price effects. The estimate for steel may underestimate the total effects of trade protection, given the prospects of further voluntary reductions of exports to the United States. The price increase for sugar is the largest and thus affords the greatest amount of protection. The International Trade Commission's decisions for footwear and television sets have been replaced by "orderly marketing agreements," which may be less severe than the costs of the commission's original recommendations. The costs of these recommenda- 
Table 11. The Effect of Recent Extensions of Trade Protection, 1975-77

\begin{tabular}{|c|c|c|c|c|c|c|}
\hline \multirow[b]{3}{*}{$\begin{array}{l}\text { Commodity } \\
\text { affected by } \\
\text { extension }\end{array}$} & \multirow[b]{3}{*}{$\begin{array}{c}\text { Increase } \\
\text { in jobs } \\
\text { (number) }\end{array}$} & \multicolumn{5}{|c|}{ Annual total cost of protection } \\
\hline & & \multirow[b]{2}{*}{$\begin{array}{l}\text { Increase } \\
\text { in price } \\
\text { (percent) }\end{array}$} & \multicolumn{2}{|c|}{ Millions of 1977 dollars } & \multicolumn{2}{|c|}{1977 dollars } \\
\hline & & & $\begin{array}{l}\text { Cost to } \\
\text { consumers }\end{array}$ & $\begin{array}{l}\text { Deadweight } \\
\quad \text { loss }\end{array}$ & $\begin{array}{l}\text { Consumer } \\
\text { cost per } \\
\text { job gained }\end{array}$ & $\begin{array}{l}\text { Deadweigh } \\
\text { loss per } \\
\text { job gained }\end{array}$ \\
\hline Sugara & n.a. & 28.6 & 660 & 56.6 & n.a. & n.a. \\
\hline Carbon steela & 20,000 & 3.0 & 1,254 & 105.5 & 62,700 & 5,275 \\
\hline Meat & n.a. & $2-4$ & $400-800$ & $4.7-18.9$ & n.a. & n.a. \\
\hline \multicolumn{7}{|c|}{$\begin{array}{l}\text { Initial ITC } \\
\text { recommendations } s^{b}\end{array}$} \\
\hline Television sets & s 9,170 & 20.0 & 500 & 116.0 & 54,526 & 12,650 \\
\hline Footwear & 21,000 & 20.0 & 1,200 & 75.0 & 57,143 & 3,571 \\
\hline
\end{tabular}

Sources: Based on data in "Comments of the Council on Wage and Price Stability," submitted to the International Trade Commission, meat investigations TA-201-25 and 332-85 (CWPS-252, July 12, 1977); ibid., submitted to the ITC, television receivers investigation TA-201-19 (CWPS-227, January 18, 1977); and ibid., testimony before the ITC, docket TA-201-18 (importation of footwear) (CWPS-217, December 7, 1976). n.a. Not available.

a. Author's estimates.

b. These recommendations were not implemented in full but were replaced by orderly marketing agreements, for which the cost estimates are not available. The costs of the initial recommendations by the International Trade Commission shown in the table are presumably upper limits of the ultimate costs of the agreements.

tions are included to demonstrate the degree of trade protection possible. The effect of the orderly marketing agreements cannot be estimated with data presently available. Excluded from the table are high tariff or nontariff barriers from decisions reached in earlier years, such as those affecting textiles, because these have been fully accommodated by the market and are unlikely to be eased.

The cost of trade protection is generally large in relation to the increase in employment generated. In those cases for which data are available the average cost to consumers for each job protected is more than $\$ 50,000$ a year. Deadweight losses are also large, ranging up to $\$ 12,650$ per additional job per year.

If the intent of Congress is to protect inefficient U.S. industry, it is difficult to see how the above costs can be reduced materially. However, if protection is seen as a temporary political response to the employment difficulties created for a small number of workers, a less inflationary and less costly form of income support is available.

Temporary subsidies to labor could be made available in affected industries, although these subsidies should probably decline in time to 
insure that inefficient U.S. industry is not perpetuated unnecessarily. Moreover, the subsidies must not be in effect so long that they distort investment and production decisions. Lowering the cost of labor for an industry that is losing comparative advantage could lead to the creation of additional capacity and to the substitution of labor for capital. These effects would simply compound the difficulties of eventual adjustment to changes in comparative advantage.

Subsidies to labor could be targeted at those employees most likely to be laid off because of import competition, but such identification is undoubtedly difficult. Moreover, substitution would take place between subsidized and unsubsidized workers. As a result, a subsidy policy would probably have to be general to the industry. Assume that Congress decided that rehiring 20,000 steelworkers was desirable in 1977 , and that a subsidy was offered to steel firms for all employees. Given approximately 360,000 hourly workers in the industry, an annual subsidy of more than $\$ 3,750$ could be paid for every employee in the industry, and the total cost would be no higher than that of the import policy of the Trade Act of 1974. This would reduce the hourly cost of labor by approximately 14 percent, which should be sufficient to induce a 5.6 percent increase in employment. Moreover, the cost of steel would not be raised by this form of assistance.

Traditional trade assistance is designed to ease the transition of workers and firms to new lines of activity after import competition has affected them. Workers or employers are not provided benefits until excess capacity and unemployment becomes a reality. The Trade Act of 1974 liberalized the eligibility criteria for adjustment assistance and appeared to recommend that assistance rather than trade restrictions. ${ }^{38}$

Although trade adjustment assistance for employees can amount to as much as 70 percent of forgone wages, such assistance generally offsets only a small share of the capital losses suffered by a firm that has lost its market to imports. Both employers and employees will generally gain more from trade protection than from assistance. Thus, the assistance allowed under the 1974 Trade Act has not reduced protectionist pressures.

38. See Charles R. Frank, Jr., Foreign Trade and Domestic Aid (Brookings Institution, 1977), chaps. 4, 5. 


\section{The Minimum Wage}

The minimum wage is an excellent example of the use of priceenhancing legislation to redistribute income in a manner that cannot be sustained politically through direct government payments. The beneficiaries of a legislated minimum wage are not principally the low-wage, low-income population, but a number of groups who compete in the labor market with these less fortunate workers.

At the beginning of the Carter administration, the AFL-CIO launched a major effort to increase the minimum wage from $\$ 2.30$ an hour, which was established for 1976 as a result of the Fair Labor Standards Amendments of 1974. The minimum wage level, which had averaged 52 percent of straight-time (nonovertime) hourly earnings in manufacturing in the last half of the 1960 s, had fallen to 44 percent of this benchmark by January 1977 . There were proposals to increase it gradually by indexing it to the average manufacturing wage. Alternatively, one proposal given serious consideration (the Dent bill) would have raised the minimum wage to 60 percent of the manufacturing wage by January 1978.

The final legislation, the Fair Labor Standards Amendments of 1977, which became effective in November, raised the minimum to $\$ 2.65$ an hour in January $1978, \$ 2.90$ in January $1979, \$ 3.10$ in January 1980 , and $\$ 3.35$ in January 1981. This replaced a Senate proposal to index the wage to 52 percent of the straight-time average hourly earnings of production workers in manufacturing in January 1979 and 53 percent in January $1980 .^{39} \mathrm{At}$ the time of passage, these percentages were projected to yield minimum wages equal to those finally legislated. Thus, the final Senate and House agreement merely replaced the indexation approach with equivalent projected wages. ${ }^{40}$

None of the innovative suggestions designed to reduce the impact of the minimum wage on the emploability of low-income teen-agers was

39. Fair Labor Standards Amendments of 1977, S. Rept. 95-440, 95:1 (GPO, 1977).

40. There are a few other minor changes in the minimum wage. The tip credit is being reduced gradually from 50 percent to 40 percent. The exemption for small retail and service establishments is being gradually liberalized. The act also introduces a simplified form for certificating students. 
adopted. The Senate report argues that there are no employment effects. Economic studies generally show just the opposite-that increases in the minimum wage result in unemployment for low-wage workers. Edward Gramlich shows that these effects may not be large and, with unemployment insurance, may not reduce the welfare of low-wage adult workers. ${ }^{41}$ But minimum wages have a most undesirable effect on teen-agers, shifting employment from full-time to part-time work.

To estimate the price effects of the increased minimum wage, I employ Gramlich's result-that each 1 percent increase in the minimum wage increases average wages by 0.032 percent. The first-year increase to $\$ 2.65$ an hour is a 15.2 percent rise, which should increase average wages in 1978 by 0.5 percent. This will produce an estimated increase in total private wages and salaries of approximately $\$ 3$ billion.

If the purpose of enacting a minimum wage is to increase the income of low-wage workers, more efficient strategies could be found that would not adversely affect the price level or employment. A wage subsidy program, such as the one announced by the administration in its urban program, could be paid to those firms employing workers from certified lowincome families. This would target the program at the desired population rather than raise the wage for teen-agers from high-income families who may be working in jobs near the minimum wage level. The only major drawback to such a program may be its tendency to induce employers to substitute eligible potential workers for existing workers, some of whom may only be marginally above the poverty level. But such a program financed from general revenues would have avoided increasing labor costs by $\$ 3$ billion in 1978 .

\section{Other Policy Initiatives}

The government could also undertake a number of other initiatives, a few of which are summarized in this section. Some proposals, such as hospital cost control, might have significant effects on the price level; others, such as pursuing a more aggressive antitrust policy, are likely to have less impact.

41. Edward M. Gramlich, "Impact of Minimum Wages on Other Wages, Employment, and Family Incomes," BPEA, 2:1976, pp. 409-51. 


\section{HOSPITAL COST CONTROL}

Hospital cost containment, a regulatory policy designed to have salutary effects on the price level, was advocated by the Carter administration in 1977, but it has failed to win the support of the Congress. Because of the tax deductibility of health insurance, the lack of coinsurance and deductibility provisions in insurance payment policies, and the absence of market competition among hospitals, there is little market discipline in the provision of hospital services. Without any restraining forces, expenditures for hospital care have recently been rising at an annual rate of about 15 percent a year. A hospital cost-containment policy limiting the rate of growth in hospital revenues to the rate of increase in the gross national product deflator plus one-third the difference between the recent average annual rate of growth in hospital expenditures and the GNP deflator (approximately 3 percent) would have reduced the growth in hospital expenditures by 2.6 percent if it had begun in fiscal year 1978 . Assuming that 80 percent of the reduction would be reflected as price changes, the net saving would be 2.1 percent of $\$ 72$ billion, or $\$ 1.5$ billion (in fiscal year 1978 dollars).

\section{RESTRAINT IN FEDERAL PAY INCREASES}

A large budget item for the federal government is its nondefense payroll-approximately $\$ 22.5$ billion in 1977 . These wages do not, however, enter directly into costs and prices; hence, reducing them or restraining the government's annual cost-of-living increases will not directly reduce the private deflator or the consumer price index. A reduction in the increase to be granted this year could, however, have some impact on wages in the private sector through its effect on wage demands and offers in skill markets in which government workers participate. (Moreover, any policy to limit these increases could provide a salutary example of broader wage-price policies.) The magnitude of this impact on wages in the private sector cannot be determined in a paper of this scope.

One suggestion offered to the President is that he reduce the annual increase by 0.5 to 1.0 percentage point from the target submitted to him based on "comparability" with the private sector. This reduction might be applauded, given recent evidence that federal workers are now paid 
13 to 20 percent more than their counterparts in the private sector. ${ }^{42}$ Based on the 1977 level of federal compensation of nondefense employees, the saving from such a cut would be in the range of $\$ 112$ million to $\$ 225$ million annually.

\section{AGGRESSIVE ANTITRUST POLICY}

A common view of inflation in the past few years has been that monetary and fiscal authorities are unwilling to hold nominal GNP to a steady growth rate in the face of sharp increases in oil, agricultural, or other commodity prices. Instead, they have been accommodating, allowing nominal GNP to rise as a result of these disruptive changes. Forcing other prices and wages downward through restrictive monetary and fiscal policies generates huge welfare losses in the form of unemployed resources, which occur because of the general inflexibility of these other wages and prices. The transitional costs of this unemployment are too much for a politically responsive administration to bear.

But if it is this inflexibility of wages and prices that so limits traditional policy tools, could some structural remedies be provided to increase price-wage flexibility? There are several reasons why the answer to such a question is decidedly negative.

First, the empirical evidence on the effects of concentration on price flexibility is at best mixed. ${ }^{43}$ While there is some evidence that prices respond more slowly to changes in demand in moderately concentrated industries than in atomistic or highly concentrated industries, this pattern has not been consistent over successive business cycles.

Equally important is the sectoral structure of the U.S. economy. In 1976 , more than one-fourth of all national income originated in government and regulated industries. ${ }^{44}$ While some of these latter industries may

42. Sharon P. Smith, Equal Pay in the Public Sector: Fact or Fantasy (Princeton University, Industrial Relations Section, 1977), p. 132.

43. See Ralph E. Beals, "Concentrated Industries, Administered Prices and Inflation: A Survey of Recent Empirical Research" (Council on Wage and Price Stability, 1975; processed); and Phillip Cagan, "Changes in the Recession Behavior of Wholesale Prices in the 1920's and Post-World War II," Explorations in Economic Research, vol. 2 (Winter 1975), pp. 54-104.

44. Estimates of the sectoral structure are based on national income without capital consumption adjustment by industry. Survey of Current Business, vol. 57 (July 1977). 
become more competitive over the next few years (stock brokerage and air transportation), there is little chance that much of this 26 percent will move to a nonregulated, competitive category with flexible wages and prices. Moreover, a good deal of mining and manufacturing-particularly the energy industries-may become less competitive as government regulation continues to supplant market forces.

Of the remaining 74 percent of national income, roughly 44 percent is currently derived from basically competitive sectors: wholesale and retail trade, most services, agriculture, and construction. There are concentrated industries within these categories, although competitive reform is unlikely to occur there.

Serious attempts to increase competition could possibly succeed in mining and manufacturing, which comprise only 27.5 percent of total national income. Manufacturing is already rather unconcentrated: only 1.8 percent of value added in manufacturing is found in industries in which the four-firm concentration ratio exceeds 67 percent. Another 18 percent derives from industries with concentration ratios between 50 and 66 percent. Antitrust policy aimed at less-concentrated industries would be exceedingly difficult to implement and might be counterproductive if the resulting firms were operating below their most efficient output level.

\section{A Summary of Policy Proposals}

As this paper has shown, a number of proposed policies could be launched as part of the effort to reduce the price level, while pursuing the search for the appropriate longer-run policy to control inflation. Given the heterogeneous nature of the proposals offered, it is difficult to summarize them neatly or concisely. Some cannot be quantified on the basis of present evidence and within the scope of this paper. Others could be modified in a number of ways to satisfy other policy goals and at the same time could have some beneficial effects on the price level. The effects of some prospective policies that can be quantified are tabulated in table 12.

Clearly, the largest potential effects-assuming the difference in incidence between direct and indirect taxation-are to be found in altering social security and sales taxation. The substitution of direct taxes for indirect state taxes could produce a 1.6 percent decline in the private 
Table 12. Summary of Policy Proposals to Reduce the Price Level

\begin{tabular}{|c|c|c|}
\hline \multirow[b]{2}{*}{ Proposal } & \multicolumn{2}{|c|}{ Potential reduction } \\
\hline & $\begin{array}{l}\text { Annual amount } \\
\text { (billions of } 1977 \text { dollars) }\end{array}$ & $\begin{array}{l}\text { In gross private } \\
\text { domestic deflator } \\
\quad \text { (percent) }\end{array}$ \\
\hline \multicolumn{3}{|l|}{ Social security } \\
\hline $\begin{array}{l}\text { Replace employer and employee payroll } \\
\text { taxes with general revenue financing for } \\
\text { disability and health insurance (fiscal 1979) }\end{array}$ & 14.6 & $0.7 \mathrm{a}$ \\
\hline \multicolumn{3}{|l|}{ Sales taxes } \\
\hline $\begin{array}{l}\text { Reduce state sales taxes up to } 2 \\
\text { percentage points of personal income }\end{array}$ & 27.4 & 1.6 \\
\hline Replace federal excise taxes with direct taxes & 17.4 & 1.0 \\
\hline \multicolumn{3}{|l|}{ Agriculture } \\
\hline $\begin{array}{l}\text { Substitute deficiency payments for } 1977-78 \\
\text { wheat, feed grain, soybean, milk initiatives }\end{array}$ & 3.6 & 0.2 \\
\hline $\begin{array}{l}\text { Substitute deficiency payments for set-aside } \\
\text { proposals designed to raise farm income } \\
\text { by } \$ 4.4 \text { billion }^{b}\end{array}$ & 4.4 & 0.3 \\
\hline \multicolumn{3}{|l|}{ Government regulation } \\
\hline $\begin{array}{l}\text { Pursue deregulation of airlines, trucking, and } \\
\text { the coastal maritime trade }\end{array}$ & 5.3 to 10.4 & 0.3 to 0.6 \\
\hline $\begin{array}{l}\text { Impose a shadow budget on social regu- } \\
\text { latory agencies }\end{array}$ & $\begin{array}{l}\text { Unmeasurable with } \\
\text { present data }\end{array}$ & $\ldots$ \\
\hline Increase federal timber cut & 0.3 & 0.02 \\
\hline $\begin{array}{l}\text { Require fully incremental costing of all } \\
\text { imported liquid and synthetic natural } \\
\text { gas }\end{array}$ & $\begin{array}{l}\text { Unknown, but up to } \\
36.0\end{array}$ & Up to 2.2 \\
\hline $\begin{array}{l}\text { Reassess best-available-control-technology } \\
\text { amendment to Clean Air Act }\end{array}$ & 1.0 to 2.0 & 0.06 to 0.12 \\
\hline \multicolumn{3}{|l|}{ Foreign trade } \\
\hline $\begin{array}{l}\text { Substitute direct subsidies for meat, steel, } \\
\text { and sugar import restraints }\end{array}$ & 2.3 to 2.7 & 0.1 to 0.2 \\
\hline \multicolumn{3}{|l|}{ Minimum wage } \\
\hline $\begin{array}{l}\text { Replace } 1978 \text { minimum-wage increase } \\
\text { with employment incentives }\end{array}$ & 3.1 & 0.2 \\
\hline \multicolumn{3}{|l|}{ Hospital cost control } \\
\hline Impose limited cost controls (fiscal 1978) & 1.5 & 0.09 \\
\hline
\end{tabular}

Source: Compiled from information in the text.

a. Based on projection of fiscal 1979 gross domestic private product.

b. This is approximately the effect of some agricultural legislation being considered in the Congress as of this writing. 
domestic deflator. General revenue financing of disability insurance and health insurance funding in social security could lead to another 0.7 percent decline in fiscal 1979.

The remaining policy initiatives are perhaps less important in terms of their prospective effects on the price level, but each one is to be strongly recommended on grounds of economic efficiency and internal consistency between stated policy goals and their attainment. For instance, changes in agricultural policy that would stress income supports instead of price supports could reduce the private deflator by a total of 0.2 percent (for the 1977-78 changes in agricultural policy), but such changes would also allow market forces to allocate agricultural resources far more efficiently. Avoiding the price increases in proposals now before the Congress would prevent another 0.3 percent rise in the deflator.

A reform of the basic constraints on regulatory agencies might have relatively minor effects on the price level (while increasing the benefits from reducing undesirable externalities), but it would improve the efficiency of regulators in mandating the flow of scarce resources for social purposes. Reform of transportation could lower the private domestic deflator by as much as 0.6 percent (without calculating any effect upon railroad rates), and it would clearly reduce economic waste in this vital sector of the economy.

Minor changes such as increasing the timber cut on federal lands or instructing the Federal Energy Regulatory Commission to pursue incremental pricing of synthetic natural gas or imported liquid natural gas would have relatively immediate effects upon the price level, but the latter policy could have much greater long-term benefits. Similarly, hospital cost control would not have a major impact on the price level, compared with other initiatives, but it would reduce the excessive flow of resources to a sector that is not governed by usual market forces.

A change from protectionism to adjustment assistance has been prescribed elsewhere. A reversal of the recent extensions of protection would have relatively small effects on the price level, but if older restraints (such as those applying to textiles and clothing) were replaced, the effect could be much greater. And the efficiency gains would be large if trade protection were removed in favor of easing the burden on displaced workers and capital.

Finally, the increases in the minimum wage legislated in 1977 could be repealed in favor of programs that more effectively and efficiently redis- 
tribute labor incomes. The effects on the price level of this change would be substantial as would the prospective effects on employment of teenagers.

None of these proposals solves the inflation problem, but a combination of a number of them might reduce the rate of increase in the price level for some time. They may be especially useful as part of a broader program aimed at wage-price moderation. Even if the effect of these initiatives on inflation proves to be minor or short-lived, most would have salutary effects on economic efficiency. The increase in gross national product should certainly be greater than the administrative and transitional costs required to put these reforms into effect. 


\section{Comments and Discussion}

Edward M. Gramlich: Robert Crandall has written a most useful species of what in government parlance might be called an options paper. He reviews a wide variety of actions the government could take to reduce price levels-many of these in fact reversing actions already taken to increase price levels-and provides the benefits and costs of these suggested actions and their effect on overall prices. In general, most of the actions appear to be attractive for their efficiency gains as well as for their inflation-reducing impact.

Because inflation is the subject of the conference, I begin by commenting on the relationship between one-shot reductions in the price level and inflation reductions. Assume the two-equation mainline model of backward-looking inflation (similar to the model in George Perry's paper and also used by Arthur Okun):

$$
\begin{gathered}
\frac{\Delta P}{P}=\frac{\Delta W}{W}-b \\
\frac{\Delta W}{W}=a_{0}+a_{1}\left(\frac{\Delta P}{P}\right)_{-1}+a_{2}\left(\frac{\Delta W}{W}\right)_{-1},
\end{gathered}
$$

where $P$ refers to prices and $W$ to wages. The parameter $a_{0}$ depends on unemployment, other proxies for demand, or both, and perhaps it also depends on whether a tax-based incomes policy exists. I assume that $a_{0}$ (and implicitly unemployment) is fixed because I am not considering demand: in particular, this implies that the one-shot increase in real money that follows any one-shot reduction in price levels is neutralized. The parameters $a_{1}$ and $a_{2}$ divide backward-looking inflation into pricewage and wage-wage components, and may either sum to one (if the model were accelerationist) or not. Most of the policies Crandall de- 
scribes can be viewed as one-shot, nonmaintained increases in the shift parameter $b$.

It can be shown that if the model were accelerationist $\left(a_{1}+a_{2}=1\right)$, the permanent impact on the rate of inflation of a unit change in $b$ would be $a_{1}$, the price-wage feedback component of the accelerationist model. If the model were not accelerationist $\left(a_{1}+a_{2}<1\right)$, there would be no permanent reduction in the rate of inflation, although for any path of real output, inflation will be slower for a number of periods, with the amount of slowdown declining in each period. If the model were forward looking, it is doubtful that there would be any price effect on wages. And there would be none if inertia were entirely a wage-wage process. Hence, it takes a rather particular view of inflation to translate one-shot price level reductions into significant permanent inflation reductions-it has to be accelerationist, backward looking, and primarily a price-wage type all at the same time. While many empirical models actually have this form, as Perry's paper indicated, that may be because with real world data it is difficult to draw a fine distinction between this form and others. But many people would question the applicability of this model of inflation in the case of one-shot, nonrecurring changes in price levels. If that is the case, the inflation-reducing potential of the measures Crandall discusses could be quite modest, although some of the measures may still be an important part of a whole package geared to alter near-term inflationary expectations in the United States in 1978.

My biggest surprise concerning the measures was the low potential given to antitrust policy. This results primarily from simple multiplication-only 27.5 percent of national income is generated in the relatively concentrated unregulated manufacturing and mining sectors, and less than 20 percent of that portion is concentrated. Moreover, after a possible one-shot reduction in price levels, all that could be expected from antitrust policy would be an increase in price flexibility, and this would be anti-inflationary on balance only when the unemployment rate averaged above the nonaccelerating rate of unemployment. Hence, apart from the subtleties that Crandall does not discuss-price leadership reactions and the fact that pass-through may not be dollar-for-dollar but may be disproportionately influenced by industries early in the production chain - there seems to be relatively little possibility of gain.

The most promising measure Crandall considers is the reduction of payroll tax rates by financing the disability and hospitalization portions 
of social security through general revenues. If done completely, this would reduce employer contributions by $\$ 14.6$ billion in fiscal 1979 and, if shifted forward completely, it would lower price levels by as much as 0.7 percent. Whether the price reduction is this large or not, and the inflation reduction is permanent or temporary, such a measure clearly seems desirable on grounds of both economic efficiency and distributional equity.

The other potentially significant action, at least in dollar terms, is Okun's proposal for a general sales tax reduction. This one is not as appealing once Crandall holds it up to close inspection. There is not much scope for reducing federal excise taxes; the only important one remaining that is not justified by an obvious social externality is the telephone excise. There is no obvious reason why this should not be cut, but it will not amount to much in dollar terms. The bigger game is for state sales taxes: when, say, state sales taxes up to 2 percent of personal income are replaced with a combination of federal and state and local income taxes, price levels would be reduced as much as 1.6 percent or $\$ 27$ billion in 1977. Crandall divides the replacement equally between the state and the federal income tax, but I believe the present state preference for sales taxes would be less strong than this implies, and the federal government should be able to accomplish its end with a grant of less than $\$ 13$ billion. The calculation can be made even more attractive: because sales tax rates are rising over time, if a reduced rate had to be maintained, the effect on price levels would grow through time. But there is a fundamental and important problem with the measure that goes back to the difference between levels and rates of price changes: presumably to gain this revenue shift, the federal government would have to make continuing grant payments. Assuming only a modest permanent reduction in inflation rates from this policy, in 1982 the federal government would still be paying for a temporary reduction in the price level of 1978, while realizing little change in the 1982 inflation rate. The federal government could always stop payment, but then what is to prevent states from restoring their sales tax? Is the federal government, after stopping payments, going to sue states that got money back in 1978 but now in 1982 let sales tax rates rise again? If so, the government will have to write it into the law now, and then I think the odds that states will accept the grant and this future constraint on their fiscal policies are drastically reduced.

Finally, I would like to comment on the proposals Crandall considers for social and environmental regulation. I fully agree with him that there 
is a structural imbalance in the process for making these decisions: unlike most other programs where the cost is an observed budget cost and the antagonist is the Office of Management and Budget, social and environmental regulations impose unobserved social costs with no natural antagonists. Something should be done at least to factor these social costs into the decisionmaking process, but exactly what is unclear.

Crandall reviews two options, one of which I do not like and one I do. These options are reversing property rights, or making the government buy nonpollution from polluters, and providing regulators with a shadow budget. Crandall rejects the first as politically impossible. I would reject it as just plain wrong. To keep government costs down it is necessary to adopt an approach such as buying nonpollution only from current-day polluters; otherwise, anybody could say that they were intending to pollute and receive a payment for not doing so. Even this limited scheme has the disadvantage of rewarding those who behave in a socially undesirable manner. However, the second option-allowing an agency such as the Office of Management and Budget (OMB) to monitor social costs as well as budget costs-seems to me to be a great idea. A potential argument against it is that social costs are more difficult to estimate than budget costs; but it is not obvious that this is true or relevant. Costs of new programs (such as Medicaid and the C5A plane) are always difficult to estimate, and benefits cause even more problems. But if it is a budget expenditure, people tend to plunge ahead anyway, making decisions as well as they can. I see no underlying efficiency or equity differences between the average social expenditure program and the average social regulation program: in both cases, benefits are possibly important but often vague and unmeasurable, and costs can be stated in terms of resources given up -whether these resources are taxed away or are required to be spent on safety or antipollution. And in both cases, OMB might be the natural watchdog. Why not simply broaden the charter of OMB, have it ask all agencies for an estimate of the nonbudget costs of their regulatory actions, and then let the expanded budget process work as the regular process does now? This will not constrain new regulation programs any more than it now limits new budget programs. If the benefits of a regulation program are substantial and the costs minimal, the program ought to be successful. But the new procedure could alter a decision process that now ignores the social costs of regulation programs, national health insurance, and the like. 
Robert E. Hall: Crandall's paper provides an opportunity to discuss the effectiveness of policies to reduce the consumer price index by shifting government finance from indirect to the direct taxation of income. The paper is written as if this were desirable on the grounds that it would give a temporary respite from inflation. I think that most participants at this meeting agree.

I find the argument for moving toward more taxation of income less convincing. It seems to me that the argument rests on an illusion created by the conventions of the CPI, which includes excise taxes and government-mandated high prices, but does not measure the adverse effect of income taxes. Consider an alternative: a comprehensive cost-of-living index, which is defined as the amount of income needed before taxes to purchase the standard market basket of goods now used to define the CPI. In my view, this is the index that people should be concerned about in discussing the cost of living and the rate of inflation.

What happens when one of Crandall's reforms is instituted, and subsequently prices fall and the income tax is raised to provide the same amount of subsidy? Note that it is necessary to abstract from a large amount of advocacy of simple government economy that appears in the paper. The introduction of the reform policy would achieve no economy; rather, it would result in a shift from higher prices to higher income taxes. The official CPI would fall, and initially people might think they had higher real incomes. But the comprehensive index would agree with common sense: real incomes would be unaffected by the change, at least to a first approximation. The notion that the policy would be deflationary is no more than an illusion of the CPI. Real incomes can rise only if the policy eliminates deadweight loss. This is the efficiency issue that Crandall does not discuss.

But there is more to the story because the objective of the shift to income taxation was to intervene in the inflationary process, not just to raise real incomes. Suppose, first, that various initiatives that Crandall discussed were adopted and that there were no other responses of monetary and fiscal instruments beyond the increase in income taxes that was part of the initiatives. The public's total dollar income would fall due to the increase in income taxes, and the volume of expenditures would also fall because of the reduction in prices. Money demand would consequently fall, and real output would rise to restore equality of supply and 
demand in the money market. This is the basic logic of the argument that changes from higher prices to higher income taxes are expansionary, and I find it persuasive. It implies that money demand is not raised by the increase in income tax collections; rather, this demand is lowered by changing the composition of consumers' disbursements.

As I mentioned above, the comprehensive cost-of-living index would not record any significant change as a result of the reform policy. The macroeconomic effect of a policy that reduced prices by 1 percent while holding the comprehensive index constant would be the same as that of an increase in the money supply of 1 percent with prices held constant. If the monetary expansion is undesirable because it eventually would worsen inflation, the policy of reduced prices and increased income taxes is undesirable on the same grounds. The smokescreen of the reduction in the CPI would conceal a move that was actually inflationary.

Advocates of the strategy of lowering prices and raising income taxes are not satisfied with the amount of expansion that naturally accompanies the policy. They propose to take advantage of the temporary lowering of the rate of inflation as recorded by the CPI to expand the economy even more. But, again, this rests on the CPI illusion. The rate of inflation as measured by the comprehensive cost-of-living index would not fall when the policy was introduced, and would rise subsequently in response to the expansion.

I have overstated the case against this kind of policy by neglecting two important points. First, economists still lack a good explanation of why inflation is bad. The inflation I described that would be measured by the comprehensive cost-of-living index would be accompanied by an equal inflation in wage rates, and would leave real incomes unaffected. Because it is not known why any kind of inflation is bad, it is difficult to argue that one index is better than another as a measure of inflation. It is possible that the only costs of inflation are psychological, and those costs will be attached to whatever price index the government decides to publish. In that case, an index like the CPI that admits a "gimmick" for a temporary reduction in reported inflation is actually superior to the comprehensive index that reveals that a policy is no more than a gimmick. Then Crandall's policies become games that the government plays with the populace, although as Arthur Okun constantly reminds us, there are games where the prizes are measured in tens of billions of dollars.

The second point is that the CPI is important despite its conceptual 
flaws because labor contracts are often indexed to it. Any policy that depresses the CPI limits the wage increases paid to workers with cost-ofliving escalators. This kind of policy offers the potential of slowing down the momentum of inflation, but at the cost of some inequity in wage rewards. Those who adopt cost-of-living escalators rely on the CPI as the best available measure of the cost of living, and may feel cheated if the government introduces a new policy that deliberately lowers the CPI without affecting that cost.

Much of Crandall's paper discusses policies that are not mere substitutions of direct taxes for indirect taxes. In fact, many of those policies eliminate deadweight losses now created by the government and so offer genuine reductions in inflation and increases in real incomes. Policies of this kind include deregulation of transportation, reform of national forest management, improved pricing of natural gas, and elimination of the minimum wage. In other cases it is unclear how much of the price reduction represents elimination of deadweight loss. Rolling back regulations of the Occupational Safety and Health Administration, auto safety regulations, and so on would reduce the prices of the products directly affected, but there may be an offsetting loss of the more general benefits of these programs that ought to be considered in any true measure of the cost of living.

Nevertheless, Crandall makes a good case that there is much deadweight loss in these programs as they are now administered. Unhappily, though, the policies whose quantitative potentials are the largest are also those that are almost pure substitutions of one tax for another, and can only be called gimmicks. Examples of these are the replacement of social security payroll taxes with income taxes, and the substitution of direct taxes for state general sales taxes. Besides the distributional argument in favor of the former, all policies are justified only by the desirability of lowering prices without affecting the comprehensive cost of living. The various policies suggested sum to a total reduction of about 4.9 percent in the price level-including deregulation, which would yield a reduction of 0.5 percent, and neglecting the two policies in table 12 that do not carry estimates and incremental costing of natural gas. Of this, 3.3 percent derives from pure tax substitutions, and no claim is made that any increase in real incomes would follow from them.

There is a danger of placing too much weight on the effects of various government programs on the price level-the sort of thinking that goes 
with an "inflation impact statement." Some desirable moves are highly inflationary-today, any sensible energy policy, either the President's or a more free-market one, is bound to raise the price level, but it is still a good idea. Bad policies like subsidies for the railroad industry may gain support from their depressing effect on the price level. In some countries, the adoption of policies mainly on the strength of their effects on the cost-of-living index has gone to absurd lengths. It would be undesirable for the United States to start in that direction.

Robert Crandall: Both Gramlich and Hall question whether policies directed toward lowering the price level in discrete steps could reduce the rate of inflation, but nothing in my paper suggests that these policies, once promulgated, would necessarily reduce the subsequent upward march of prices and wages. Indeed, I am as agnostic on the issue as Hall and Gramlich. Perry's paper does not rule out a price-wage effect, but whether it is large enough to permit an anti-inflationary dynamic to be introduced by discrete government-induced reductions of the price level remains an open question.

I am somewhat puzzled by Hall's focus on the distinction between a true cost-of-living indicator and the consumer price index. My paper attempted to demonstrate the possibilities for reducing the price levelwhich could be defined as one or another of the indexes of market prices. It did not suggest that reductions in the price level, per se, increase real income. Nor is the exercise in the spirit of promoting deception as a government policy. Any policy that attempts to intervene in the inflationary process will probably affect someone's real income. Whether substituting direct for indirect taxes is more unfair than reducing the rate of growth of the money supply is not a question that I pretend to answer.

It is true, as Gramlich believes, that the efficiency gains for various policies would be a worthwhile basis for advocating them even if they have no lasting anti-inflationary effect. Unfortunately, as Hall notes, the largest efficiency gains exist in those proposals with the more modest price-level effects. However, it should be noted that I have only scratched the surface in detailing initiatives that would undo the misallocative effects of existing government policy. This choice was deliberate because I was interested in focusing on policy choices that are relevant in today's political climate. Thus, for instance, I examined import restrictions on sugar and steel while avoiding the multifiber agreement. Similarly, I analyzed current 
programs for wheat, cotton, and feed grain while ignoring the myriad of market-order programs that keep the U.S. Department of Agriculture busy.

There seems to be some confusion about my proposals for reform of social regulation. First, Hall sees them as attempts to roll back some regulatory programs that have social value. While I am sure that there are instances in which "rolling back" may be appropriate, this is not my objective. It is only to seek some mechanism by which regulators can be made to realize that they are mandating the use of scarce resources when they pursue their various social goals. Gramlich's questioning of my proposal to reverse property rights in some instances suggests some misunderstanding of my proposal. I would only use this mechanism for existing sources of externalities, and the price paid by the government to these sources for ceasing their damaging activity would become the tax paid by new sources to the government for originating new social changes. While I think that such a proposal is theoretically sound, I am not optimistic that it could be explained to the public.

\section{General Discussion}

Part of the discussion focused on the anti-inflationary effectiveness and potential of the general strategy of reducing the cost and price level. Rudiger Dornbusch took issue with Robert Hall's emphasis on the "comprehensive" cost-of-living index. He interpreted Hall's index as a measure of the purchasing power of income, but he also saw reasons to measure the purchasing power of money as the consumer price index did. $\mathrm{He}$ noted that a reduction in the CPI could have important economic effects, even if it were not accompanied by a reduction in Hall's type of index. So long as anti-inflationary monetary policy was influenced by monetary growth targets, a lower inflation rate of the CPI would lead to a greater expansion of real output. Franco Modigliani, however, qualified that conclusion, pointing out that it was true if money demand depended on gross national product, rather than on gross national income-an issue that he considered unsettled. William Brainard supported Dornbusch's general point that the CPI mattered, pointing to its role in labor negotiations and other economic decisions. He saw a case for changing the index used in wage escalator clauses to exclude price increases reflect- 
ing payments to foreigners (that is, rising import prices) or higher costs due to increased collective consumption (that is, improved environmental standards). But he noted that such an issue should be clearly distinguished from an analysis of the impact of the CPI on the economy, as wage determination now is conducted.

Donald Nichols thought that much of the controversy between Robert Hall's approach and that of the paper could be resolved by examining the empirical issue of whether nominal wage increases would fall in response to downward shifts in the price level. If, in fact, nominal wages respond to the price level and not to changes in direct taxes, the proposals are not gimmicks. Modigliani commented that the critical empirical issue was whether wages were determined by a wage-wage or by a price-wage mechanism (or some combination of the two). The effectiveness of the proposals discussed by Robert Crandall-unlike the TIP plans-depended on wages following prices, at least to some extent. James Duesenberry elaborated on this in terms of Edward Gramlich's formulation of the inflationary process, noting the critical role played by the coefficients of the lagged price terms. The cost-reducing proposals are more effective, not only if the coefficients are larger, but also if the lags are shorter.

Arthur Okun sought to qualify Gramlich's proposition that one-shot reductions in the price level had a permanent effect on the inflation rate only if the world were accelerationist and if it had a backward-looking price-wage feedback. First, he noted, if the world were not accelerationist, not even a recession would have a permanent effect on the inflation rate. The one-shot reduction in the price level achieved through cost-cutting would still do as much good and have as lasting an effect in slowing inflation as the same reduction achieved through a one-shot dose of extra unemployment. Second, he suggested that a forward-looking process based on rational expectations of future real wages could yield parallel results to those of the backward-looking model.

William Poole was concerned about the pitfall that economists might encounter if they advocated regulatory or tax changes merely because they were anti-inflationary. He thought that a clear distinction should be made between policies that were advocated on the grounds of efficiency and equity and those that were advanced only for anti-inflationary purposes. To him, the efficiency and equity benefits of some of Crandall's proposals were important and deserved emphasis. George Perry and Martin Baily countered that policies have numerous dimensions that 
economists should be prepared to acknowledge. For example, one might rationally favor policies for energy deregulation because of their allocative efficiency benefits even though they were inflationary. Baily insisted, however, that the inflationary costs should be recognized.

The participants were especially interested in proposals to lower the price level by substituting direct for indirect taxation. Poole saw such a strategy as an attempt to tamper with the workings of price indexes; he thought it might prove counterproductive. People would recognize the increased burden of direct taxes and take steps to preserve their real aftertax incomes by dropping the use of price indexes as a standard. Duesenberry cited experiences in Massachusetts that revealed the suspicions of voters confronted by a suggested shift from sales taxes to income taxes; he inferred that the voters saw the shift as a hidden way to increase government expenditures. To be credibly anti-inflationary, in his view a plan for a shift in the composition of taxes had to be accompanied by a ceiling on state and local spending.

Walter Heller thought that, in developing a social bargain for a wagerestraint program, a payroll tax reduction would probably be more effective than an income tax cut. The payroll tax cut would provide a clearly perceived, readily calculated increase in take-home pay for a given wage, while the benefits of income-tax cuts vary among workers doing the same job, depending on family size, deductions, and the like.

Modigliani cited evidence from studies on the Dutch and British economies that higher direct taxes raised wages and hence the price level. He thought that this issue might deserve further investigation in the United States. Modigliani noted that, to the extent that direct taxes are not significantly shifted forward in higher wages, the proper response of policy to the explosion of oil prices in 1974 would have been a large reduction of indirect taxes that neutralized the price-level impact, together with some offsetting increase in direct taxes.

In the discussion of the regulation issues raised by the paper, Charles Holt enthusiastically supported Crandall's idea of having government regulatory agencies budget the costs they imposed on the private economy. He noted that some regulatory actions had effects similar to tax collections and public expenditures but lacked a comparable technique of control under current procedures. In his judgment, the main payoff from the budgeting proposal would come from greater efficiency rather than reduced inflation. Lloyd Ulman elaborated on Holt's comments, noting 
that some problems reflected a peculiar antieconomic bias that officials of regulatory agencies develop in focusing solely on their social objectives. Martin Feldstein, however, was skeptical of the feasibility and usefulness of ex ante estimates of regulatory burdens. He doubted the quality and objectivity of such estimates and questioned the ability to detect and control "cost-overruns" ex post.

Arnold Packer saw the need for a survey of the possibilities for reforms to reduce costs and improve efficiency in the private sector. Among the areas of possible inefficiencies in private institutions, he mentioned casualty and malpractice insurance, "wild-cat" strikes, and unnecessarily wide seasonal fluctuation in construction.

Some panel members stated that certain other aspects of government policy deserved more attention than Crandall had given them. Feldstein suspected that Crandall's estimate of the inflationary effects of the increased minimum wage - based on Gramlich's work-was too low and did not fully account for its effects in shifting up the entire wage structure. Gramlich replied that, in fact, half of Crandall's estimated increase in overall wages consisted of indirect effects of the minimum wage on wages above the minimum. Crandall noted that Perry had failed to find any significant effect of minimum wages, and Ulman suggested that, in light of the empirical evidence, perhaps economists devoted too much attention to the inflationary effects of the minimum wage.

Michael Lovell and Baily felt that Crandall had underestimated the potential of more vigorous antitrust policies. Lovell mentioned that some success had been achieved in lowering legal fees, and that antitrust measures might be effective in other service branches, such as real estate and travel agents.

Heller reminded the panel that deregulatory measures took a long time to be implemented. He pointed out that actions now being taken to deregulate airlines were first proposed during the Kennedy administration. $\mathrm{He}$ counseled the current advocates of deregulation not to be discouraged if they failed to obtain prompt results. 